\title{
Measuring pH variability using an experimental sensor on an underwater glider
}

\author{
Michael P. Hemming ${ }^{1,2}$, Jan Kaiser ${ }^{1}$, Karen J. Heywood ${ }^{1}$, Dorothee C.E. Bakker ${ }^{1}$, Jacqueline Boutin ${ }^{2}$, \\ Kiminori Shitashima ${ }^{3}$, Gareth Lee ${ }^{1}$, Oliver Legge ${ }^{1}$, and Reiner Onken ${ }^{4}$ \\ ${ }^{1}$ Centre for Ocean and Atmospheric Sciences, School of Environmental Sciences, University of East Anglia, Norwich \\ Research Park, Norwich NR4 7TJ, UK \\ ${ }^{2}$ Laboratoire d'Océanographie et du Climat, 4 Place Jussieu, 75005 Paris, France \\ ${ }^{3}$ Tokyo University of Marine Science and Technology, 4-5-7 Konan, Minato, Tokyo 108-0075, Japan \\ ${ }^{4}$ Helmholtz-Zentrum Geesthacht, Max-Planck-Straße 1, 21502 Geesthacht, Germany \\ Correspondence to: Michael P. Hemming (m.hemming@uea.ac.uk)
}

Received: 29 September 2016 - Discussion started: 11 October 2016

Revised: 1 April 2017 - Accepted: 28 April 2017 - Published: 24 May 2017

\begin{abstract}
Autonomous underwater gliders offer the capability of measuring oceanic parameters continuously at high resolution in both vertical and horizontal planes, with timescales that can extend to many months. An experimental ionsensitive field-effect transistor (ISFET) sensor measuring $\mathrm{pH}$ on the total scale was attached to a glider during the REP14-MED experiment in June 2014 in the Sardinian Sea in the northwestern Mediterranean. During the deployment, $\mathrm{pH}$ was sampled at depths of up to $1000 \mathrm{~m}$ along an $80 \mathrm{~km}$ transect over a period of 12 days. Water samples were collected from a nearby ship and analysed for dissolved inorganic carbon concentration and total alkalinity to derive the $\mathrm{pH}$ for validating the ISFET sensor measurements. The vertical resolution of the $\mathrm{pH}$ sensor was good ( 1 to $2 \mathrm{~m}$ ), but stability was poor and the sensor drifted in a non-monotonous fashion. In order to remove the sensor drift, a depth-constant time-varying offset was applied throughout the water column for each dive, reducing the spread of the data by approximately two-thirds. Furthermore, the ISFET sensor required temperature- and pressure-based corrections, which were achieved using linear regression. Correcting for this decreased the apparent sensor $\mathrm{pH}$ variability by a further 13 to $31 \%$. Sunlight caused an apparent sensor $\mathrm{pH}$ decrease of up to 0.1 in surface waters around local noon, highlighting the importance of shielding the sensor from light in future deployments. The corrected $\mathrm{pH}$ from the ISFET sensor is presented along with potential temperature, salinity, potential density anomalies $\left(\sigma_{\theta}\right)$, and dissolved oxygen con-
\end{abstract}

centrations $\left(c\left(\mathrm{O}_{2}\right)\right)$ measured by the glider, providing insights into the physical and biogeochemical variability in the Sardinian Sea. The $\mathrm{pH}$ maxima were identified close to the depth of the summer chlorophyll maximum, where high $c\left(\mathrm{O}_{2}\right)$ values were also found. Longitudinal $\mathrm{pH}$ variations at depth $\left(\sigma_{\theta}>28.8 \mathrm{~kg} \mathrm{~m}^{-3}\right)$ highlighted the variability of water masses in the Sardinian Sea. Higher $\mathrm{pH}$ was observed where salinity was $>38.65$, and lower $\mathrm{pH}$ was found where salinity ranged between 38.3 and 38.65. The higher $\mathrm{pH}$ was associated with saltier Levantine Intermediate Water, and it is possible that the lower $\mathrm{pH}$ was related to the remineralisation of organic matter. Furthermore, shoaling isopycnals closer to shore coinciding with low $\mathrm{pH}$ and $c\left(\mathrm{O}_{2}\right)$, high salinity, alkalinity, dissolved inorganic carbon concentrations, and chlorophyll fluorescence waters may be indicative of upwelling.

\section{Introduction}

It is estimated that one-third of the anthropogenic carbon dioxide emitted between 2004 to 2013 was absorbed by the oceans (Le Quéré et al., 2015). Normally unreactive in the atmosphere, carbon dioxide dissolved in seawater $\left(\mathrm{CO}_{2}(\mathrm{aq})\right)$ takes part in a number of chemical reactions. In particular, carbonic acid $\left(\mathrm{H}_{2} \mathrm{CO}_{3}\right)$ forms as a result of $\left(\mathrm{CO}_{2}(\mathrm{aq})\right)$ reacting with water, which dissociates into bicarbonate $\left(\mathrm{HCO}_{3}^{-}\right)$ and carbonate $\left(\mathrm{CO}_{3}^{2-}\right)$. These seawater carbonate species are referred to as dissolved inorganic carbon concentrations 
(c(DIC), with " $c$ " representing a concentration) with $\mathrm{HCO}_{3}^{-}$ accounting for $90 \%$ of $c$ (DIC). During the dissociation of carbonate species, hydrogen ions $\left(\mathrm{H}^{+}\right)$are released. The $\mathrm{pH}$ is calculated as the negative decadal logarithm of the activity (commonly referred to as a concentration) of these $\mathrm{H}^{+}$ions. Thus the $\mathrm{pH}$ in the ocean is directly related to the activity of $\mathrm{H}^{+}$ions in the water (Zeebe and Wolf-Gladrow, 2001).

The $\mathrm{pH}$ varies on timescales spanning less than 1 day (Hofmann et al., 2011) to many years (Rhein et al., 2013). Since before the industrial revolution (year 1760), the global surface ocean $\mathrm{pH}$ has fallen from 8.21 to 8.10 (corresponding to a $30 \%$ increase in $\mathrm{H}^{+}$ion activity) as a result of the atmospheric $\mathrm{CO}_{2}$ mole fraction increasing by more than $100 \mathrm{~mol} \mathrm{~mol}^{-1}$ (Doney et al., 2009; Fabry et al., 2008). Future projections of anthropogenic carbon dioxide emissions suggest that ocean uptake of $\mathrm{CO}_{2}$ will continue for many decades, thus contributing to long-term ocean acidification (Rhein et al., 2013). This may have a significant effect on marine organisms, such as calcifying phytoplankton (e.g. coccolithophores) and corals (e.g. scleractinian), dependent on the solubility state of calcium carbonate (Doney et al., 2009).

Since 1989, it has been possible to measure $\mathrm{pH}$ to an accuracy of $10^{-3}$ using a spectrophotometric approach (Byrne and Breland, 1989). Although there have been some advances in adapting this approach to measure $\mathrm{pH}$ autonomously in situ (Martz et al., 2003; Aßmann et al., 2011), spectrophotometry is largely used for shipboard measurements, as it requires the use of indicator dye and a means to measure spectrophotometric blanks, which is challenging outside of a laboratory (Martz et al., 2010).

A limited number of hydrographic surveys have been undertaken, and stations offering long-term time series of $\mathrm{pH}$ are available (Rhein et al., 2013). However, there is a drive to improve spatial and temporal data coverage via autonomous means, similar to what was experienced for temperature and salinity with Argo floats 16 years ago (Roemmich et al., 2003). There is demand to develop a reliable autonomous sensor with a precision and accuracy of $10^{-3}$ that is affordable to the scientific community (Johnson et al., 2016).

The Mediterranean Sea comprises just $0.8 \%$ of the global oceanic surface, but it is regarded as an important sink for anthropogenic carbon due to its physical and biogeochemical characteristics (Álvarez et al., 2014). Between 1995 and 2012, surface $c$ (DIC) increased by $3 \mu \mathrm{mol} \mathrm{kg}^{-1} \mathrm{a}^{-1}$ in the northwest Mediterranean Sea, which is consistent with a rise in temperature of $0.06^{\circ} \mathrm{Ca}^{-1}$ and a decrease in $\mathrm{pH}$ of $0.003 \mathrm{a}^{-1}$ (Yao et al., 2016). In contrast, the $\mathrm{pH}$ in the neighbouring North Atlantic Ocean decreased by just $0.0017 \mathrm{a}^{-1}$ associated with an increase in $c$ (DIC) of around $1.4 \mu \mathrm{mol} \mathrm{kg}-1 \mathrm{a}^{-1}$ and a temperature rise of $0.01^{\circ} \mathrm{Ca}^{-1}$ (Bates et al., 2012). The greater potential of the Mediterranean Sea to store anthropogenic carbon can be explained by its higher alkalinity, warmer temperatures, and thus lower Revelle factor (Álvarez et al., 2014; Touratier and Goyet,
2011) when compared with other oceans, such as the North Atlantic.

The $\mathrm{pH}$ in the Mediterranean Sea is typically higher than most other oceanic regions (Álvarez et al., 2014). The pH on the total scale normalised to $25^{\circ} \mathrm{C}\left(\mathrm{pH}_{T, 25}\right)$ collected by ship between 1998 and 1999 within the northwestern Mediterranean Sea varied between 7.92 and 8.04 at the surface and between 7.9 and 7.93 at depths greater than $100 \mathrm{~m}$ (Copin-Montégut and Bégovic, 2002). When considering the Mediterranean Sea as a whole, $\mathrm{pH}_{T, 25}$ obtained by ship in April 2011 varied between 7.98 and 8.02 at the surface and between 7.88 and 7.96 at greater depths (Álvarez et al., 2014). The peak-to-peak amplitude of the annual $\mathrm{pH}$ cycle in the northwest Mediterranean Sea is typically 0.1 with maxima and minima in spring and summer, respectively (Yao et al., 2016).

Measurements of $\mathrm{pH}$ with higher temporal resolution, such as those measured by in situ sensors, can vary greatly depending on their location and depth. Hofmann et al. (2011) presented the results of 15 deployments using SeaFET $\mathrm{pH}$ sensors (Sea-Bird Scientific) close to the surface at a number of locations worldwide. They found that $\mathrm{pH}$ could vary by as much as 1.1 in extreme environments, such as those obtained close to volcanic $\mathrm{CO}_{2}$ vents off the coast of Italy, or as little as 0.02 in open ocean areas, such as in the temperate eastern Pacific Ocean, over a time period of 30 days. Hofmann et al. (2011) were able to capture diel cycles in $\mathrm{pH}$, with the most consistent variations found in coral reef locations. The $\mathrm{pH}$ was at a maximum in the early evening and at a minimum in the morning with amplitudes between 0.1 and 0.25 ; this is similar in range to other studies based in subtropical estuaries (Yates et al., 2007).

Autonomous underwater gliders offer the possibility to observe the oceanic system with a greater level of detail on both temporal and spatial scales when compared with ship measurements (Eriksen et al., 2001). A low consumption of battery power and a great degree of manoeuvrability enable such vehicles to cover large areas and profile depths of up to $1000 \mathrm{~m}$ during missions that can last from weeks to months. They are suitable platforms for a range of sensors, measuring both physical and biogeochemical parameters (Piterbarg et al., 2014; Queste et al., 2012).

This paper is a contribution to the special issue "REP14MED: A Glider Fleet Experiment in a Limited Marine Area". The main goal of this paper is to describe the trial of a novel ion-sensitive field-effect transistor (ISFET) $\mathrm{pH}$ sensor, which was attached to an autonomous underwater glider in the northwest Mediterranean Sea during the REP14-MED sea experiment. The secondary objective is to provide a method of correcting the $\mathrm{pH}$ measured by this sensor and to discuss the spatial and temporal variability observed. The experiment, the glider sensors including the ISFET sensor, and the method of validation are described in Sect. 2. The shipbased data are presented in Sect. 3.1, and a comparison between ship and glider measurements is made in Sect. 3.2.1. 


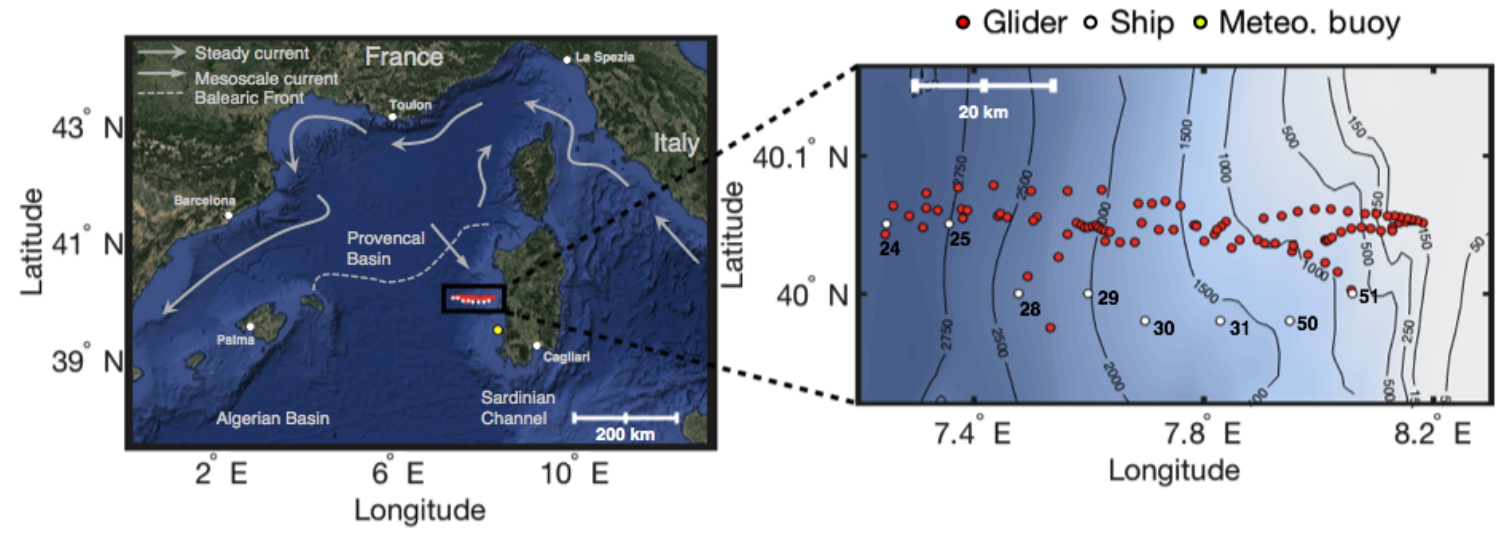

Figure 1. The locations of the 93 dives undertaken by the Seaglider (red markers), the eight ship CTD casts in which water samples were obtained (white markers), and meteorological buoy M1 (yellow marker) within the REP14-MED observational domain off the coast of Sardinia, Italy between 11 and 23 June 2014. GEBCO 1 min resolution bathymetry data (metres) were used (http://www.bodc.ac.uk/projects/ international/gebco/), and surface circulation patterns were adapted from figures presented by Millot (1999).

The initial $\mathrm{pH}$ results and validation, the method of further correcting $\mathrm{pH}$, and an artefactual light-induced effect are described in Sect. 3.2.2. Corrected $\mathrm{pH}$ measurements are analysed alongside other collected parameters in Sect. 3.2.3, and the conclusions are presented in Sect. 4.

\section{Methodology}

\subsection{REP14-MED sea trial}

This trial took place between 6 and 25 June 2014 in the northwest Mediterranean Sea off the coast of Sardinia, Italy (Fig. 1). This was part of the Environmental Knowledge and Operational Effectiveness (EKOE) research programme led by the North Atlantic Treaty Organisation (NATO) Centre for Maritime Research and Experimentation (CMRE) based in La Spezia, Italy. This was the fifth Recognised Environmental Picture (REP) trial, which was jointly conducted by two research vessels: the NRV Alliance and the RV Planet.

Eleven gliders with varying pressure tolerances were deployed during the trial, each making repeated west-east transects separated by roughly $0.13^{\circ}$ of latitude from one another within the REP14-MED observational domain. One of these gliders was operated by the University of East Anglia (UEA): an iRobot Seaglider model 1KA (SN 537) with an ogive fairing. All gliders were deployed to meet the objectives of the trial, such as to improve ocean forecasting techniques (e.g. model validation and evaluation of forecasting skill), conduct a cost-benefit analysis of autonomous gliders, analyse mesoscale and sub-mesoscale features, and test new glider payloads. The latter objective was perhaps the most relevant to the deployment of the UEA glider. A more indepth overview of the REP14-MED trial, its objectives, and the collected observational data is described by Onken et al. (2016).
The UEA glider completed a total of 126 dives between 11 and 23 June 2014. The first 24 dives did not record $\mathrm{pH}$ and the last 9 dives were very shallow, leaving 93 usable dives. Successive dives were approximately 2 to $4 \mathrm{~km}$ apart, descending to depths of up to $1000 \mathrm{~m}$.

\subsection{Glider sensors}

Conductivity, pressure, and in situ temperature measurements were obtained by the glider using a Sea-Bird Scientific glider payload CTD sensor (Bellevue, WA, USA; Fig. 2). These measurements were then used to obtain potential temperature $(\theta)$ and practical salinity.

Dissolved oxygen concentrations $\left(c\left(\mathrm{O}_{2}\right)\right.$, where " $c$ " refers to a concentration) were measured using an Aanderaa 4330 oxygen optode sensor (Aanderaa Data Instruments, Bergen, Norway) positioned towards the rear of the glider fairing (Fig. 2). The method of calibrating $c\left(\mathrm{O}_{2}\right)$ closely followed that described by Binetti (2016), using the oxygen sensor engineering parameters TCPhase and CalPhase, which will be summarised here. The first step involved correcting $c\left(\mathrm{O}_{2}\right)$ to account for the response time $(\tau)$ of the sensor, as the diffusion of oxygen across the silicon foil of the sensor is not an instantaneous process. Each oxygen sensor has a different $\tau$, which depends on the structure, thickness, age, and usage of the foil (McNeil and D'Asaro, 2014), as well as the external environmental conditions such as temperature. An average $\tau$ of $17 \mathrm{~s}$ was obtained using the method outlined by Binetti (2016). After correcting the TCPhase for $\tau$, glider TCPhase profiles were matched in time and space with pseudo-CalPhase profiles back-calculated from the measurements of $c\left(\mathrm{O}_{2}\right)$ obtained by the ship Sea-Bird Scientific SBE 43 sensor (CTD package) using the manufacturer's set of optode calibration equations. The relationship between the glider TCPhase and the ship pseudo-CalPhase was established, and the calculated slope and offset coefficients were 


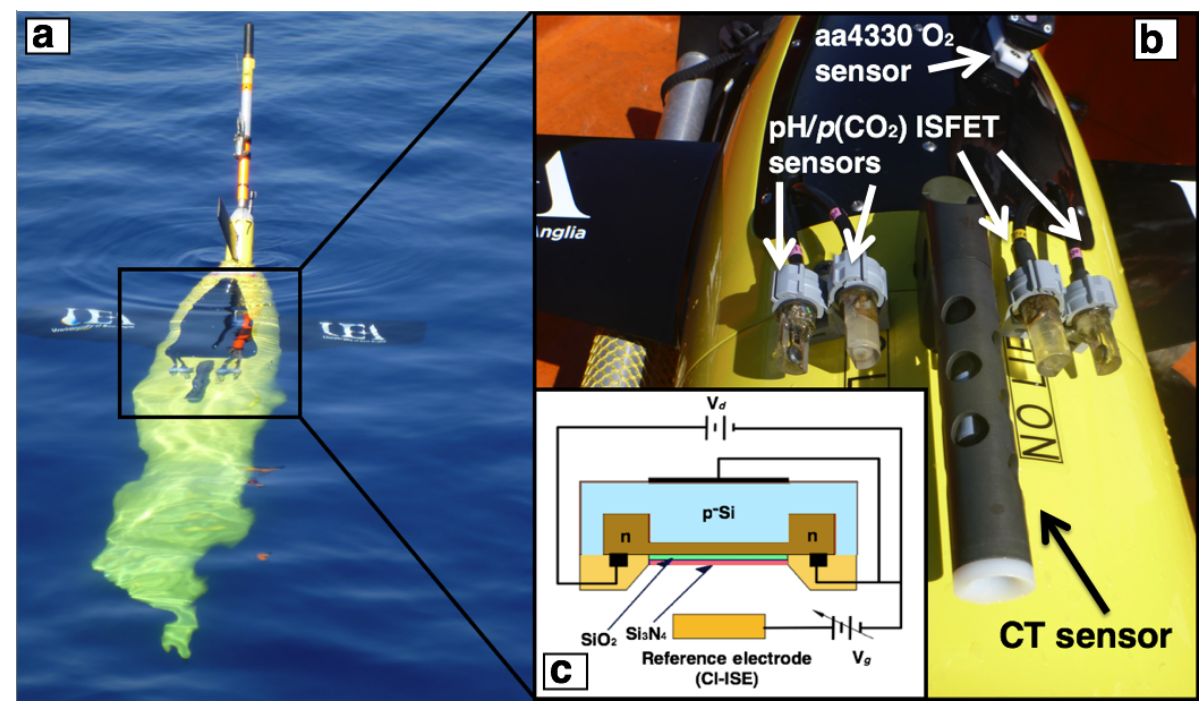

Figure 2. (a) Seaglider SN 537 during the deployment: (b) a close-up of the sensors and (c) a schematic diagram of the ISFET sensor adapted from Shitashima (2010).

used to correct the glider CalPhase, which is required for calibrating $c\left(\mathrm{O}_{2}\right)$ measurements. A comparison between the ship $c\left(\mathrm{O}_{2}\right)$ measurements and the calibrated glider $c\left(\mathrm{O}_{2}\right)$ measurements is made in Sect. 3.2.1.

Glider variables have been processed using an opensource MATLAB-based toolbox (https://bitbucket.org/ bastienqueste/uea-seaglider-toolbox/) in order to correct for differing timestamp allocations, sensor lags (Garau et al., 2011; Bittig et al., 2014), and to tune the hydrodynamical flight model (Frajka-Williams et al., 2011). Outliers outside of a specified range (e.g. 6 standard deviations) were flagged and not used for analysis, and glider profiles were smoothed using a lowess low-pass filter with a span of 5 data points ( $<4 \mathrm{~m}$ range), which implements a local regression using weighted linear least squares and a first-order polynomial linear model. Individual profiles were inspected afterwards to ensure that potentially correct data points were not removed.

The ISFET pH sensor used in this study (Fig. 2) was custom built by a working group led by Kiminori Shitashima at the Tokyo University of Marine Science and Technology (previously the University of Kyushu), and it is not commercially available. The ISFET unit was housed in acrylic resin material. The ISFET unit and the reference chlorine ion-selective electrode (Cl-ISE) were moulded with epoxy resin in the custom-built housing. The ISFET $\mathrm{pH}$ unit was stand-alone, meaning that the sensor was not integrated into any of the onboard glider electronics. The power source of the sensor was $10.5 \mathrm{~V}$ supplied by three $3.5 \mathrm{~V} \mathrm{Li}$-ion batteries.

The glider also carried another ISFET $\mathrm{pH}$ sensor that was integrated into the glider electronics (Fig. 2) and two $p\left(\mathrm{CO}_{2}\right)$ sensors (Shitashima, 2010), one stand-alone and one inte- grated. The data retrieved from the integrated $\mathrm{pH}$ sensor and the $p\left(\mathrm{CO}_{2}\right)$ sensors could not be used due to quality issues. We think the regular on/off cycling of power to the integrated dual $\mathrm{pH}-p\left(\mathrm{CO}_{2}\right)$ sensor between sampling did not allow it to function properly. In future, we would suggest the addition of backup batteries to supply power to the sensor between sampling. The cause of the problem with the stand-alone $p\left(\mathrm{CO}_{2}\right)$ unit is unclear.

To measure $\mathrm{pH}$, the activity of $\mathrm{H}^{+}$ions is determined using the interface potential between the Cl-ISE and the semiconducting ion-sensing transistor coated with silicon dioxide $\left(\mathrm{SiO}_{2}\right)$ and silicon nitride $\left(\mathrm{Si}_{3} \mathrm{~N}_{4}\right)$. The ISFET $\mathrm{pH}$ sensor was previously found to have a response time of a few seconds with an accuracy of $0.005 \mathrm{pH}$ and suitable temperature and pressure sensitivities (Shitashima et al., 2002, 2013; Shitashima, 2010). Before deploying the sensor, the ISFET and Cl-ISE were conditioned (as recommended by Bresnahan et al., 2014 and Takeshita et al., 2014) in a bucket of local sea surface water with a salinity of 38.05. However, due to time constraints, conditioning took place over just 1 hour rather than weeks as specified by Bresnahan et al. (2014) and Takeshita et al. (2014). During the deployment, pH measurements were obtained vertically every 1 to $2 \mathrm{~m}$.

The measurements obtained by the ISFET $\mathrm{pH}$ sensor were converted from raw output counts to $\mathrm{pH}$ on a total scale using a two-point calibration with 2-aminopyridine (AMP) and a 2-amino-2-hydroxymethil-1, 3-propanediol (TRIS) buffer solution before and after the deployment of the glider. The same buffer solutions (Wako Pure Chemical Industries, Ltd., Osaka, Japan) created in synthetic seawater $(S=35$, ionic strength of around $0.7 \mathrm{M}$ ) were used before and after deployment. These buffer solutions had a $\mathrm{pH}$ of $6.79 \pm 0.03$ (AMP) and $8.09 \pm 0.03$ (TRIS). The $\mathrm{pH}$ uncertainty of the 
buffer solutions takes into account the effect of changing air temperature, ranging between 30.5 and $33.3^{\circ} \mathrm{C}$ during pre-calibration and between 27.5 and $28^{\circ} \mathrm{C}$ during postcalibration. A linear fit using the raw output measured from these buffer solutions was used to convert the raw counts to pH (Shitashima et al., 2002). A drift was observed between the $\mathrm{pH}$ of these buffer solutions before and after the deployment, which was corrected for. As the ISFET sensor was previously described as having a pressure-resistant performance and good temperature characteristics for oceanographic use (Shitashima et al., 2002; Shitashima, 2010), no compensations for temperature and pressure were performed on the ISFET measurements at this stage. The ISFET $\mathrm{pH}$ sensor has a salinity sensitivity of $\partial \mathrm{pH} / \partial S=0.011$, which was taken into account. The effect of biofouling on the ISFET $\mathrm{pH}$ measurements, as well as on all other glider measurements, was ruled out after a post-deployment inspection of the sensors indicated no problems.

\subsection{Ship-based measurements}

As the in situ ISFET $\mathrm{pH}$ sensor was under trial, some form of validation of the results was required. In total, 124 water samples were collected from Niskin bottles sampled at 12 depths (down to $1000 \mathrm{~m}$ ) using a CTD rosette platform at eight locations (eight casts, numbered 24-51) close to the path of the glider (Fig. 1). Water samples were collected between 05:19 local time (LT, UTC+2) on 9 June and 16:58 LT on 11 June. The glider ISFET $\mathrm{pH}$ sensor started operating at 16:36 LT on 11 June. Overall, the measurements obtained by the glider and the CTD overlapped better in space than in time (Fig. 3).

When collecting carbon samples, water was drawn into $250 \mathrm{~mL}$ borosilicate glass bottles from Niskin bottles on the CTD rosette using tygon tubing. Bottles were rinsed twice before filling and were overflowed for $20 \mathrm{~s}$, allowing the bottle volume to be flushed twice. Each sample was poisoned with $50 \mu \mathrm{L}$ of saturated mercuric chloride and then sealed using greased stoppers, secured with elastic bands, and stored in the dark (Dickson et al., 2007). The total alkalinity $\left(A_{\mathrm{T}}\right)$ and the $c$ (DIC) of each water sample was measured in the laboratory using a Marianda Versatile INstrument for the Determination of Titration Alkalinity (VINDTA 3C; www.marianda.com). The $c$ (DIC) was measured by coulometry (Johnson et al., 1985) following standard operating procedure SOP 2 , and $A_{\mathrm{T}}$ was measured by potentiometric titration (Mintrop et al., 2000) following SOP 3b, both described by Dickson et al. (2007). During the analytical process, 21 bottles of certified reference material (CRM; batch 107) supplied by the Scripps Institution of Oceanography (San Diego, CA, USA) were run through the instrument to keep track of stability and to calibrate the instrument. For each day in the lab, one CRM was used before and after the samples were processed. A total of 19 concurrent replicate-depth water samples were collected with around 2 to 3 replicates per CTD cast. Calculating the mean stan- dard deviation of these replicate samples enabled a measurement of the instrument precision. The mean standard deviations of the $c$ (DIC) and $A_{\mathrm{T}}$ replicates were $1.7 \mu \mathrm{mol} \mathrm{kg}{ }^{-1}$ and $1.4 \mu \mathrm{mol} \mathrm{kg}{ }^{-1}$, respectively. This corresponds to a $\mathrm{pH}$ uncertainty of 0.003 for $c$ (DIC) and $A_{\mathrm{T}}$, resulting in a combined uncertainty of 0.009 .

Once $A_{\mathrm{T}}$ and $c$ (DIC) were known, $\mathrm{pH}$ could be derived using the CO2SYS programme (Van Heuven et al., 2011). This calculation has an estimated $\mathrm{pH}$ probable error of around 0.006 due to uncertainty in the dissociation constants $p K_{1}$ and $p K_{2}$ (Millero, 1995). Temperature and salinity were obtained from the Sea-Bird CTD sensor on the ship rosette sampler, and the seawater equilibrium constants presented by Mehrbach et al. (1973) were used as refitted by Dickson and Millero (1987), which has been recommended by previous studies (e.g. the CARINA data synthesis project) for the Mediterranean Sea (Álvarez et al., 2014; Key et al., 2010). The sulfate constant described by Dickson (1990) and the parameterisation of total borate presented by Uppström (1974) were used. More information on the equilibrium constants used in CO2SYS and other available carbonate system packages is described by Orr et al. (2015). The pH derived from the water samples collected by ship and the glider-retrieved ISFET $\mathrm{pH}$ are both on the total $\mathrm{pH}$ scale (as described by Dickson, 1984) at in situ temperature and will from now on be referred to as $\mathrm{pH}_{\mathrm{s}}$ and $\mathrm{pH}_{\mathrm{g}}$, respectively.

Standard deviation ranges will from this point be listed when referring to variability in measurements, such as $\mathrm{pH}_{\mathrm{s}}$ and $\mathrm{pH}_{\mathrm{g}}$. To obtain these standard deviation ranges, data points for a given variable were sorted into $10 \mathrm{~m}$ depth bins down to a maximum depth of $1000 \mathrm{~m}$. The standard deviation was then calculated for each bin.

\section{Results and discussion}

\subsection{Ship-based data}

Measurements obtained by the ship CTD package provide an overview of the temporal and spatial variability for the time at which the water samples used to derive $\mathrm{pH}_{\mathrm{s}}$ were collected (Fig. 4). The $\theta$ gradient was strong in the top $100 \mathrm{~m}$ of the water column due to limited vertical mixing with a maximum between 19 and $23^{\circ} \mathrm{C}$ found in the upper $10 \mathrm{~m}$ of the water column, decreasing to between 13 and $14^{\circ} \mathrm{C}$ at depths greater than $100 \mathrm{~m}$. The salinity was low in the top $100 \mathrm{~m}$, increasing to a maximum at around 400 to $600 \mathrm{~m}$. These fresher waters in the top $100 \mathrm{~m}$ are likely modified Atlantic water (MAW), typically having a salinity between 38 and 38.3 in the northwest Mediterranean Sea (Millot, 1999). These waters enter from the Atlantic Ocean through the Strait of Gibraltar, flowing along the North African coast. Some water makes its way northward and follows the shelf back west towards the Atlantic Ocean (Rivaro et al., 2010; Millot, 1999). At deeper depths, warmer saltier waters were found 
(a) Spatial distribution

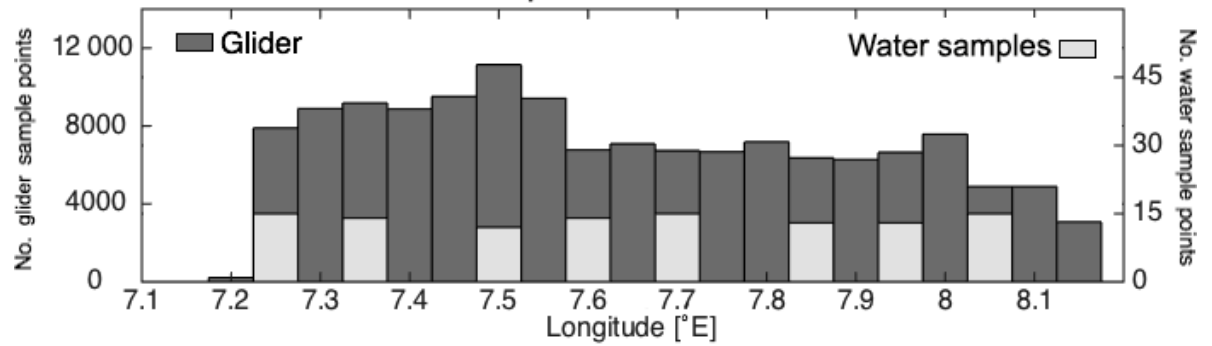

(b) Temporal distribution

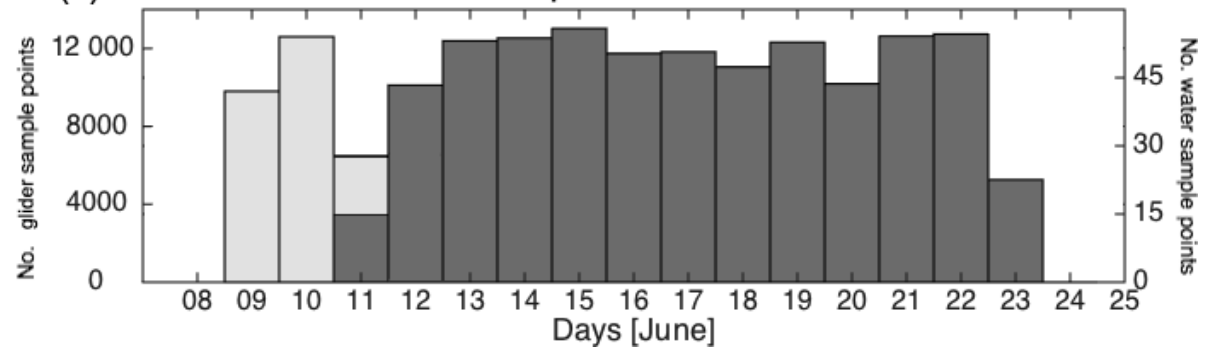

Figure 3. Histograms showing the (a) spatial and (b) temporal distribution of samples collected by the glider (dark grey) and by CTD water bottle sampling (light grey). The $y$ axis on the left is for the sum of the glider samples, whilst the $y$ axis on the right is for the sum of the water samples.

east of $7.5^{\circ} \mathrm{E}$, which is likely to be Levantine Intermediate Water (LIW) identified in the western Mediterranean Sea by a salinity range of 38.45 to 38.65 and $\theta$ between 13.07 and $13.88^{\circ} \mathrm{C}$ (Rivaro et al., 2010), typically found at depths between 200 and $800 \mathrm{~m}$ close to the shelf slope (Millot, 1999). The $c\left(\mathrm{O}_{2}\right)$ maxima were found at depths between 20 and $90 \mathrm{~m}$. The Mediterranean Sea on the whole is considered to be oligotrophic (Álvarez et al., 2014). However, a deep chlorophyll maximum (DCM) is common at these depths when waters are thermally stratified (Estrada, 1996). There is a build-up of actively growing biomass with greater cell pigment content as a result of photoacclimation due to increased concentrations of nitrate, phosphate, and silicate, as well as sufficient levels of light at these depths (Estrada, 1996). It is likely that this high $c\left(\mathrm{O}_{2}\right)$ was related to the DCM, further evidenced by the high chlorophyll fluorescence layer observed at 60 to $100 \mathrm{~m}$ of depth, particularly in the east.

The objective of deriving $\mathrm{pH}_{\mathrm{s}}$ using $A_{\mathrm{T}}$ and $c$ (DIC) was to make a comparison with the $\mathrm{pH}_{\mathrm{g}}$ measured by the ISFET sensor. The $c$ (DIC) and $A_{\mathrm{T}}$ were greatest at depths below $250 \mathrm{~m}$ with lower values seen closer to the surface (Fig. 5ab), which is typical of the northwest Mediterranean Sea (Copin-Montégut and Bégovic, 2002; Álvarez et al., 2014). The higher values of $A_{\mathrm{T}}$ and $c$ (DIC) at depth and in the east support the notion that this is LIW, as this water mass has previously been identified as having an $A_{\mathrm{T}}$ of around $2590 \mu \mathrm{mol} \mathrm{kg}^{-1}$ and a $c$ (DIC) of roughly $2330 \mu \mathrm{mol} \mathrm{kg}^{-1}$ (Álvarez et al., 2014), coinciding with the warmer saltier waters. The mean $c$ (DIC) and $A_{\mathrm{T}}$ (averages over eight casts) have standard deviations of 6.1 to 11.9 and 5.9 to
$10.6 \mu \mathrm{mol} \mathrm{kg}^{-1}$, respectively, for the top $150 \mathrm{~m}$ of the water column and 1.7 to $3.9 \mu \mathrm{mol} \mathrm{kg}-1$ and 3.7 to $7.6 \mu \mathrm{mol} \mathrm{kg}^{-1}$ for deeper waters. The $\mathrm{pH}_{\mathrm{s}}$ had a maximum of 8.14 between 50 and $70 \mathrm{~m}$ of depth (Fig. $5 \mathrm{c}$ ). The mean $\mathrm{pH}_{\mathrm{s}}$ values have standard deviations of 0.004 to 0.011 within the top $150 \mathrm{~m}$ and 0.006 to 0.017 deeper than this. A proportion of these standard deviations can be explained by the instrumental error associated with the analysis of $c$ (DIC) and $A_{\mathrm{T}}$ discussed in Sect. 2.3.

\subsection{Glider data}

\subsubsection{Temperature, salinity, and oxygen validation}

Since the sensors were calibrated before deployment, it was expected that the measurements from the glider would match those from the CTD because any discrepancies between datasets would indicate possible instrumental or methodological issues with the glider measurements. The mean profiles of $\theta$, salinity, and $c\left(\mathrm{O}_{2}\right)$ collected by the glider and by ship (Fig. 6) agreed well. The values obtained by both ship and glider were mostly within 1 standard deviation of one another. The mean $\theta$ and salinity retrieved during the eight ship $\mathrm{pH}_{\mathrm{s}}$ casts differed from the binned mean calculated using all available REP14-MED ship casts at depths between 100 and $500 \mathrm{~m}$. However, this is likely related to temporal or spatial variability as mean $\theta$ and salinity were within the range of all available glider measurements. Furthermore, differences of roughly $0.1^{\circ} \mathrm{C}, 0.02$, and $1.5 \mu \mathrm{mol} \mathrm{kg}{ }^{-1}$ can be seen for $\theta$, salinity, and $c\left(\mathrm{O}_{2}\right)$, respectively, between the binned mean profile of CTD measurements and the binned mean profile 
(a)
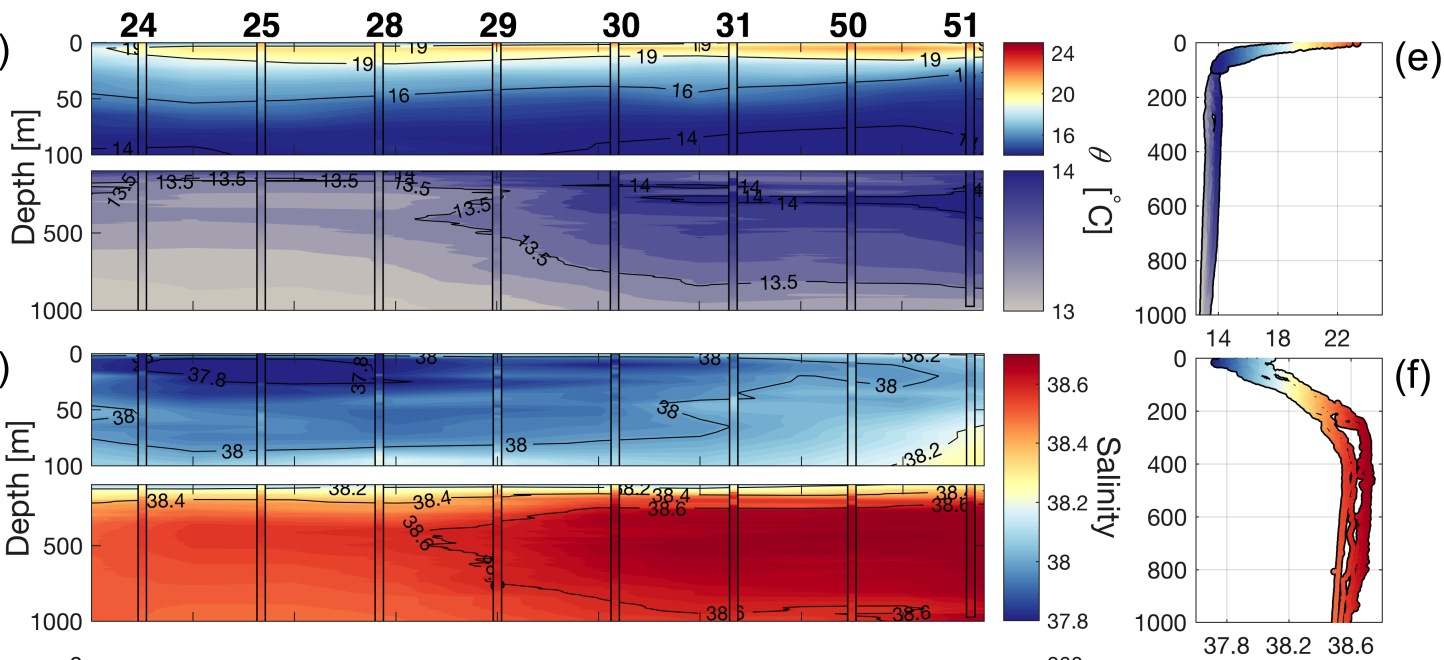

(b)

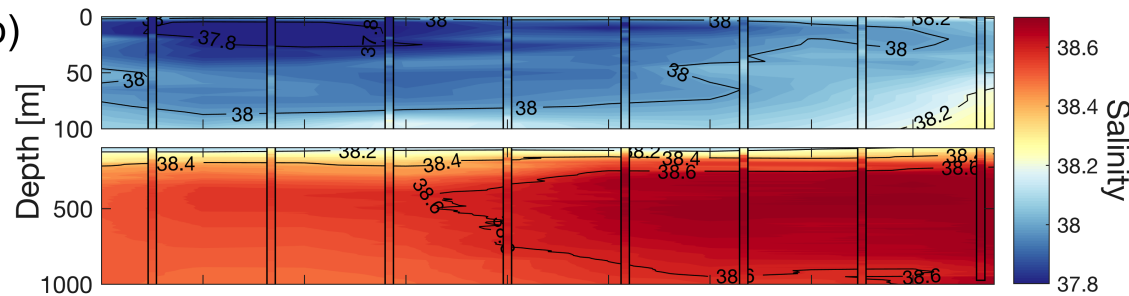

(c)
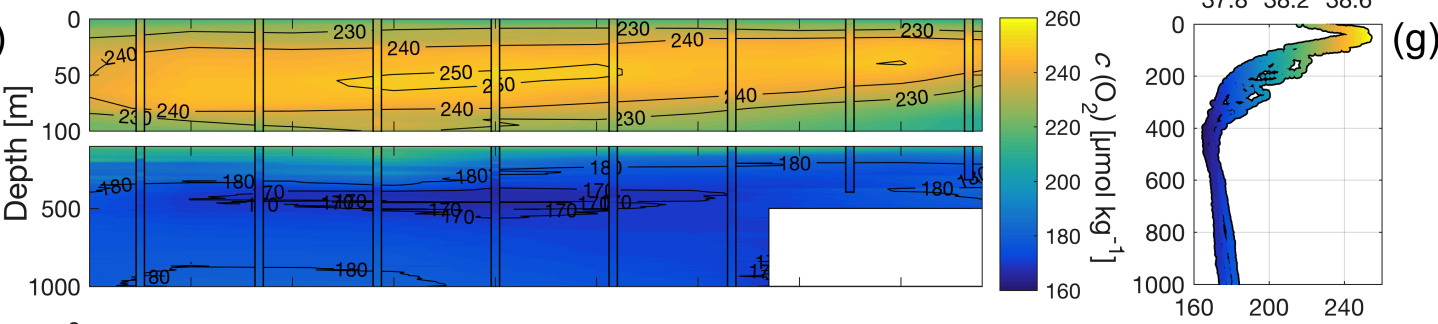

(d)
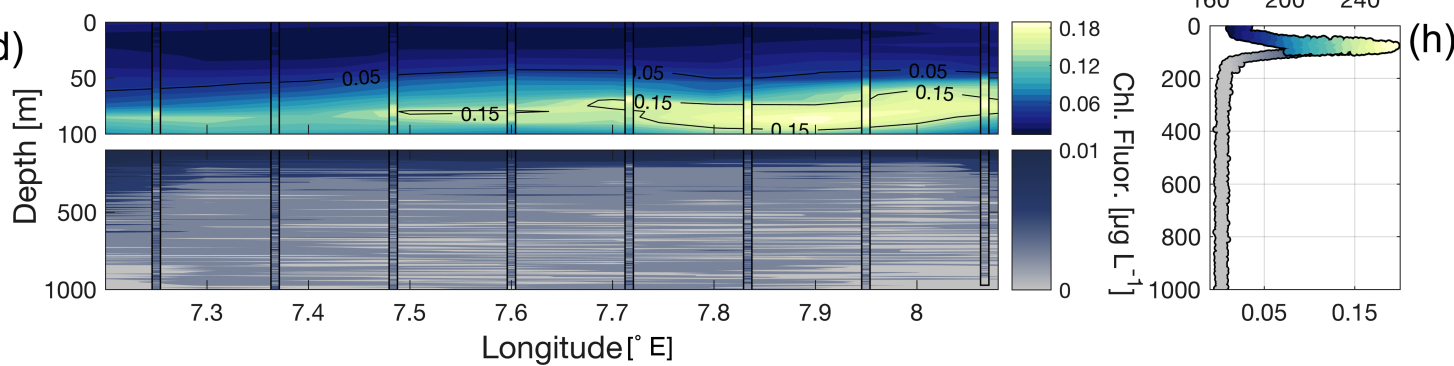

Figure 4. Transects of optimally interpolated (a) potential temperature $(\theta)$, (b) salinity, (c) dissolved oxygen concentrations $\left(c\left(\mathrm{O}_{2}\right)\right)$, and $(\mathbf{d})$ chlorophyll fluorescence, along with their depth profiles $(\mathbf{e}-\mathbf{h})$ obtained by ship. These parameters were sorted into $0.1^{\circ}$ longitude $\times 5 \mathrm{~m}$ bins, and the radius of influence used for optimal interpolation was $0.2^{\circ}$ longitude $\times 20 \mathrm{~m}$. The data retrieved during the eight CTD casts (displayed in Fig. 1) used for optimal interpolation are superimposed on the interpolated fields.

of glider measurements at depths greater than $500 \mathrm{~m}$. These differences in $\theta$, salinity, and $c\left(\mathrm{O}_{2}\right)$ are related to the different spatial distribution of the two datasets, as the glider measured predominantly at $40^{\circ} \mathrm{N}$ where deep, cooler, and fresher waters were observed in the west (Fig. 4a-b) that are uncommon in other areas of the observational domain (Knoll et al., 2015b).

\subsubsection{ISFET pH validation}

The mean $\mathrm{pH}_{\mathrm{g}}$ and $\mathrm{pH}_{\mathrm{s}}$ agreed best between 60 and $250 \mathrm{~m}$ (Fig. 7), although $\mathrm{pH}_{\mathrm{g}}$ variability was a lot higher than for $\mathrm{pH}_{\mathrm{s}}$. Larger differences between these profiles can be seen above and below this depth range, with a $\mathrm{pH}_{\mathrm{g}} 0.1$ higher at the surface and roughly 0.07 lower between 950 and $1000 \mathrm{~m}$ when compared with $\mathrm{pH}_{\mathrm{s}}$. The $\mathrm{pH}_{\mathrm{s}}$ maximum at approximately 50 to $70 \mathrm{~m}$ of depth was not apparent in the $\mathrm{pH}_{\mathrm{g}}$ pro- file, with the highest $\mathrm{pH}_{\mathrm{g}}$ seen at the surface. The standard deviations for $\mathrm{pH}_{\mathrm{g}}$ were large, ranging between 0.044 and 0.114 in the top $150 \mathrm{~m}$ of the water column and between 0.027 and 0.053 at other points in the water column. Comparing all $\mathrm{pH}_{\mathrm{g}}$ dive profiles obtained during the mission suggests a great degree of temporal and spatial variability, with $\mathrm{pH}$ ranging from 8.02 to 8.28 at the surface and between 7.97 and 8.13 at $800 \mathrm{~m}$ of depth.

A diel cycle in $\mathrm{pH}_{\mathrm{g}}$ anomalies (calculated by subtracting the all-time mean from the hourly means within a given depth interval) was found predominantly at depths shallower than $20 \mathrm{~m}$ (Fig. 8b). Lower pH was found between 09:00 and 18:00 LT, decreasing by $>0.1$ between 12:00 and 14:00 LT. Contrastingly, potential temperature, salinity, and $c\left(\mathrm{O}_{2}\right)$ anomalies (calculated in the same way as $\mathrm{pH}_{\mathrm{g}}$ anomalies) did not have strong diel cycles (Fig. 8c-e), suggesting 

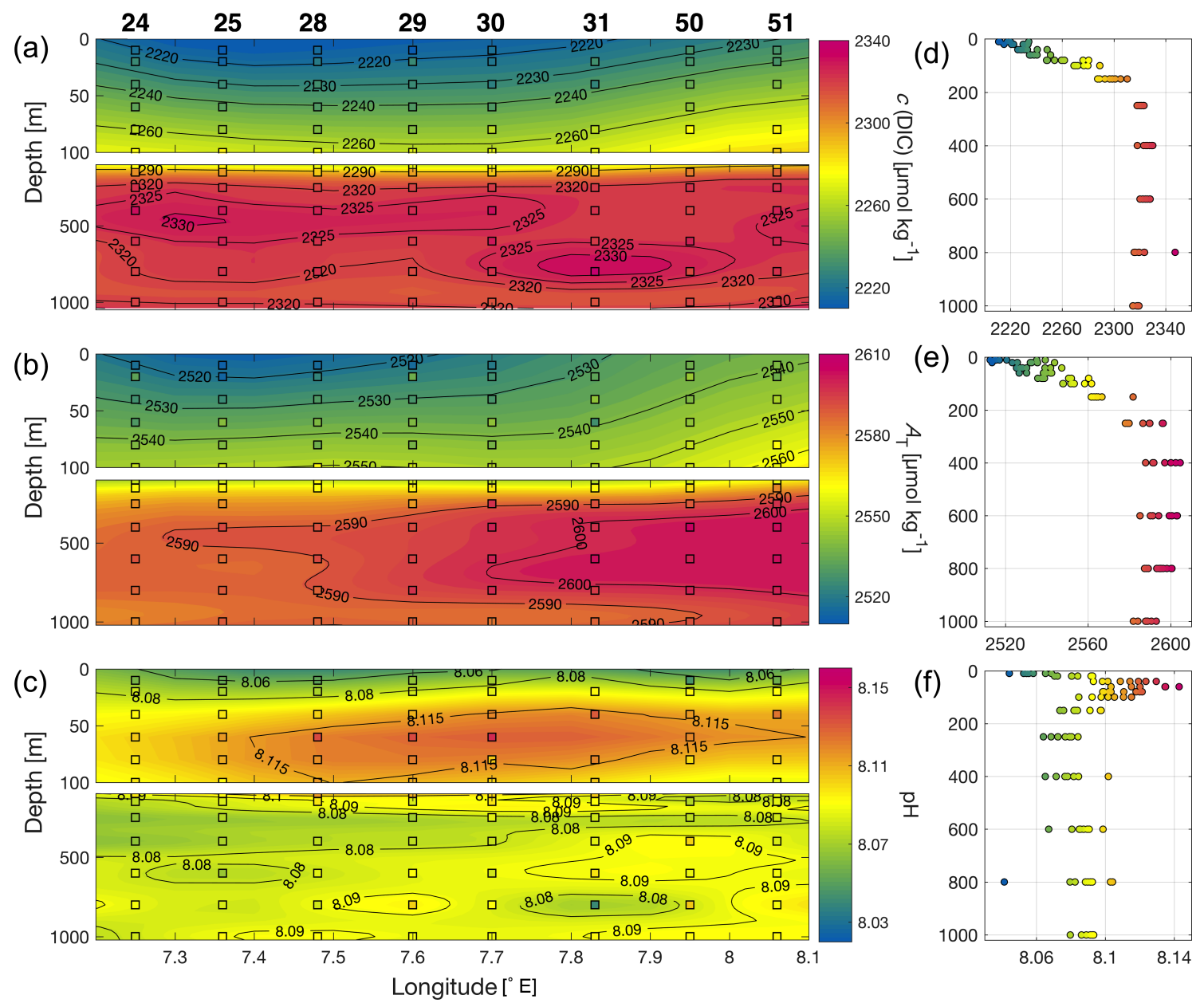

Figure 5. Optimally interpolated fields of (a) dissolved inorganic carbon ( $c(\mathrm{DIC}))$, (b) total alkalinity $\left(A_{\mathrm{T}}\right)$, and (c) $\mathrm{pH}$ derived using $c(\mathrm{DIC})$ and $A_{\mathrm{T}}$ are displayed along with their depth profiles (d-f). These parameters were sorted into $0.1^{\circ}$ longitude $\times 20 \mathrm{~m}$ bins, and the radius of influence used for optimal interpolation was $0.3^{\circ}$ longitude $\times 200 \mathrm{~m}$ for $c$ (DIC) and $\left(A_{\mathrm{T}}\right)$ and $0.3^{\circ}$ longitude $\times 80 \mathrm{~m}$ for $\mathrm{pH}$. The water sample values retrieved during the eight CTD casts (displayed in Fig. 1) used for optimal interpolation are superimposed on the interpolated fields as squares.

that the decrease in $\mathrm{pH}$ was not caused by changing environmental conditions. Particularly, one might expect $c\left(\mathrm{O}_{2}\right)$ to have a similar pattern to $\mathrm{pH}$ if it were related to photosynthesis or respiration due to variations in $p\left(\mathrm{CO}_{2}\right)$ (Cornwall et al., 2013; Copin-Montégut and Bégovic, 2002). However, $c\left(\mathrm{O}_{2}\right)$ remained relatively constant throughout the day at all depth ranges, implying that the level of biological activity in the Sardinian Sea did not change on average throughout the day and hence would not have caused this reduction in $\mathrm{pH}_{\mathrm{g}}$.

The decrease in $\mathrm{pH}_{\mathrm{g}}$ coincided with increased levels of solar irradiance (Fig. 8a) recorded at meteorological buoy M1 (Fig. 1) during the day at the surface; hence it was likely a light-induced instrumental artefact. The effect of light on the voltage output of FET-based sensors using $\mathrm{SiO}_{2}-$ and $\mathrm{Si}_{3} \mathrm{~N}_{4}$ sensitive layers is known (Wlodarski et al., 1986), as the presence of photons can excite electrons in the valence band of the semiconductor material, creating holes and allowing the flow of electrons to the conduction band. This increases the voltage threshold to falsely measure higher hydrogen ion activity, leading to lower apparent $\mathrm{pH}$ (Liao et al., 1999).

The effect of light on our sensor was investigated further by exposing two ISFET $\mathrm{pH}$ sensors to artificial light whilst placed in reference buffer solutions (TRIS and AMP) under laboratory conditions. The results (not shown here) confirmed that our ISFET sensor is affected by light. The lightinduced offset depended on the strength and type of the light source and which sensor was being used. The offset remained relatively constant whilst the light was turned on. Maximum $\mathrm{pH}$ offsets of $-0.7\left(-6 \times 10^{6}\right.$ counts $)$ and $-0.15\left(-3 \times 10^{6}\right.$ counts) were found when the LED and halogen lights were used, respectively.

There were not enough dives for a robust light correction, and an irradiance-measuring sensor was not attached to the glider; hence data collected within the top $50 \mathrm{~m}$ be- 

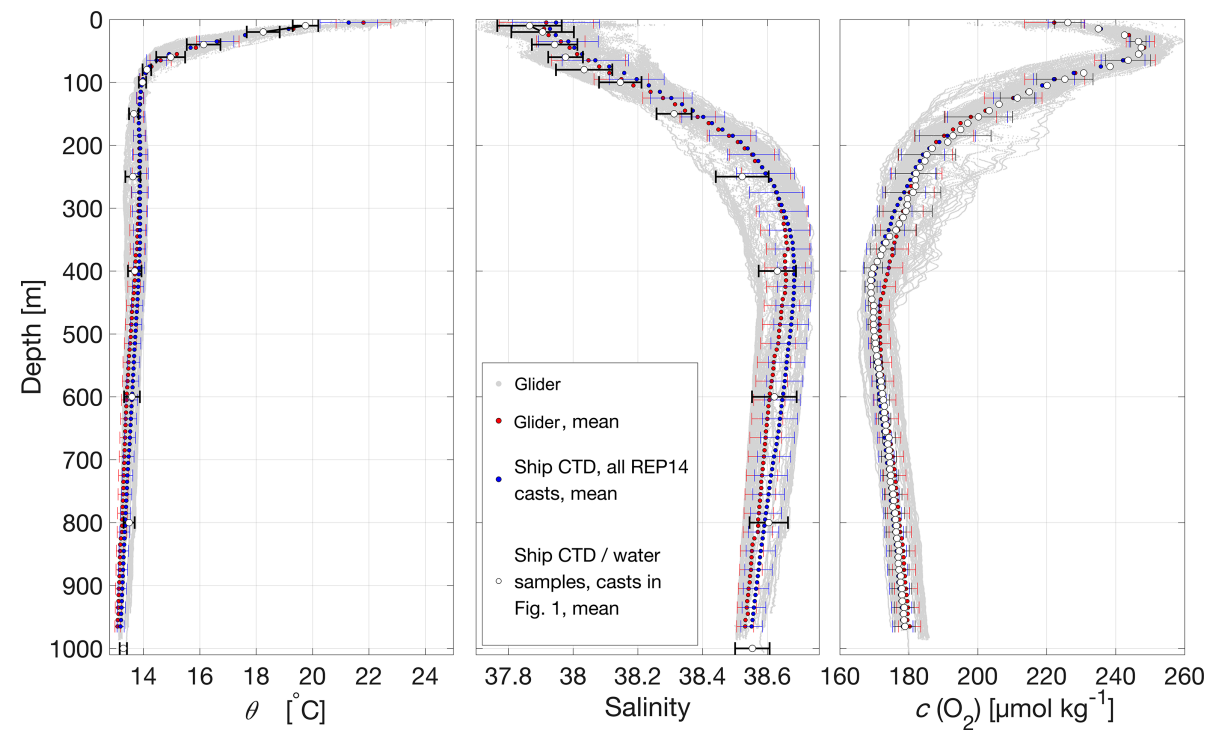

Figure 6. A comparison between the measurements retrieved by the glider and those obtained by the ship CTD package. The binned means (red) calculated using glider measurements (grey) are compared with the binned means of the CTD casts obtained from the entire REP14MED observational domain (blue) and the binned mean values obtained from water samples (SBE oxygen optode sensor for dissolved oxygen concentrations $\left(c\left(\mathrm{O}_{2}\right)\right)$ during the eight CTD casts in Fig. 1 (white) for (a) potential temperature $(\theta)$, (b) salinity, and (c) $c\left(\mathrm{O}_{2}\right)$. Standard deviations (calculated for every $10 \mathrm{~m}$ bin) are displayed as error bars in this figure every $30 \mathrm{~m}$ for glider and CTD measurements and at every sampled depth for water samples.

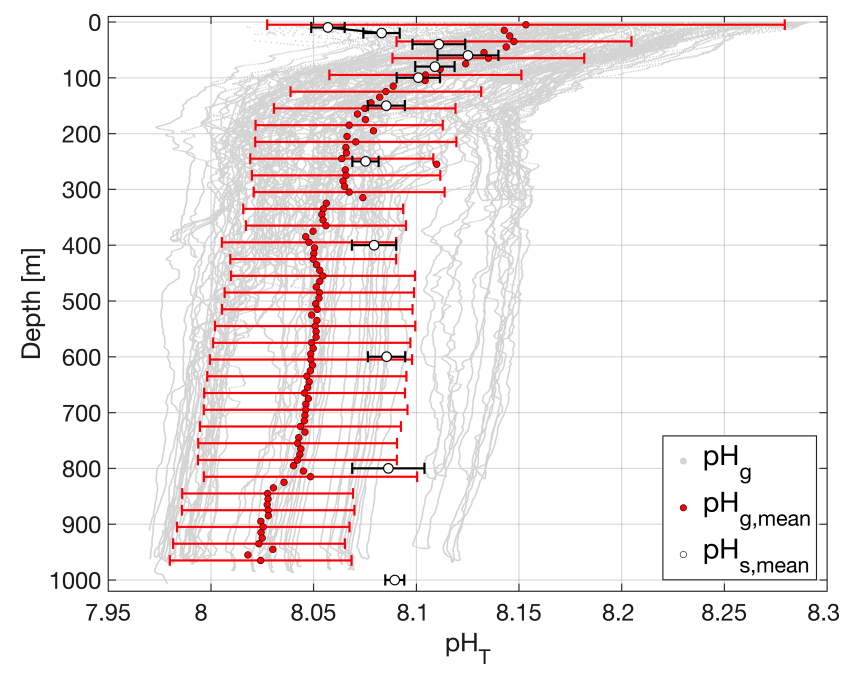

Figure 7. The $\mathrm{pH}$ obtained by the glider ISFET sensor $\left(\mathrm{pH}_{\mathrm{g}}\right.$; grey) is compared with the depth-binned mean of these profiles (red) along with the corresponding standard deviation error bars (using $10 \mathrm{~m}$ bins) displayed in this figure every $30 \mathrm{~m}$. The mean $\mathrm{pH}$ values obtained by the ship $\left(\mathrm{pH}_{\mathrm{S}}\right)$ during the eight $\mathrm{CTD}$ casts displayed in Fig. 1 are shown (white), with their relevant standard deviations displayed as error bars. The mean $\mathrm{pH}_{\mathrm{g}}$ values and their corresponding standard deviations were calculated using $10 \mathrm{~m}$ depth bins, whereas the mean $\mathrm{pH}_{\mathrm{s}}$ values and standard deviations were calculated at each sampled depth. tween 05:00 and 21:00 LT, representing roughly 5\% of all $\mathrm{pH}_{\mathrm{g}}$ measurements, were not used in later analysis. In order to reduce this light effect on $\mathrm{pH}$ measurements in future, ISFET sensors will have to be placed on the underside of the glider or equipped with a light shield.

Comparing $\mathrm{pH}_{\mathrm{g}}$ to $\mathrm{pH}_{\mathrm{s}}$ indicated that the range observed by the ISFET sensor was much larger. It could be argued that this difference in range is due to the differing temporal and spatial resolution between the glider and the ship measurements. However, comparing $\mathrm{pH}_{\mathrm{g}}$ further with $\mathrm{pH}$ measurements in the literature on a similar timescale and spatial scale (Álvarez et al., 2014) suggests that this is not an issue with resolution. The $\mathrm{pH}_{\mathrm{T}, 25}$ collected in the western Mediterranean Sea over a period of around 2 weeks (Álvarez et al., 2014), which is comparable in length to this trial, varied by roughly 0.02 at the surface and by around 0.08 at depths greater than $100 \mathrm{~m}$. The range observed by the glider ISFET sensor was therefore 13 times larger at the surface and roughly 3 times larger at depths below $100 \mathrm{~m}$. This difference in range cannot be explained by the high sampling frequency of the glider. Furthermore, the larger variations in $\mathrm{pH}_{\mathrm{g}}$ were not a result of changing environmental conditions, as evidenced by the relatively stable $c\left(\mathrm{O}_{2}\right), \theta$, and salinity measured by the glider, as discussed in Sects. 3.2.1 and 3.2.3.

It is likely that the ISFET $\mathrm{pH}$ measurements were not only related to the amount of hydrogen ion activity in the water, but also to the temperature and pressure that the sensor experienced, which was unexpected considering the sensor has previously shown good temperature and pressure character- 


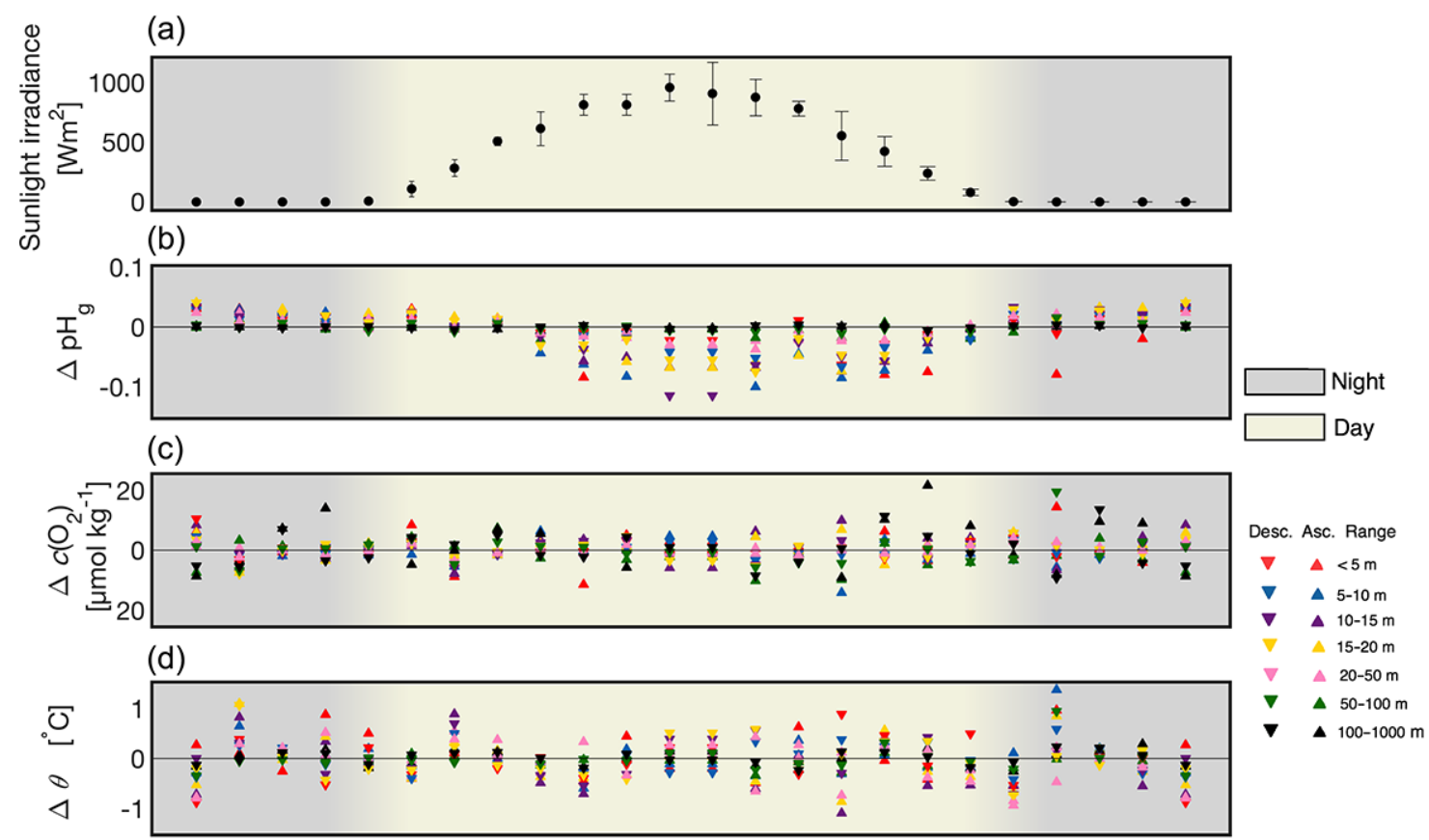

(e)

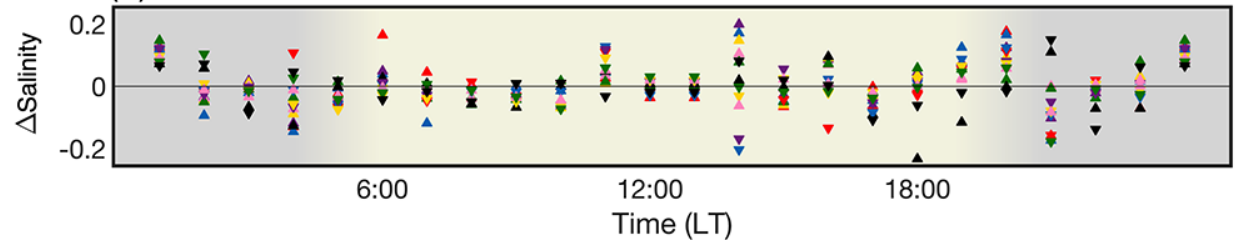

Figure 8. (a) Solar irradiance measured using a pyranometer on meteorological buoy M1 (Fig. 1). (b) Glider-retrieved $\mathrm{pH}(\mathrm{pH}$ ), (c) dissolved oxygen concentrations $\left(c\left(\mathrm{O}_{2}\right)\right)$, (d) potential temperature $(\theta)$, and (e) salinity average anomalies (calculated by subtracting the all-time mean from the hourly means within a given depth interval) for each hour of the day in local time (LT) for five near-surface depth ranges: $<5 \mathrm{~m}$, $5-10,10-15,15-20$, and 20-50 m, as well as two deeper depth ranges of 50-100 and 100-1000 m for both ascending (upward triangle) and descending (downward triangle) dive profiles. The grey shaded area represents the nighttime, whilst the lightly shaded area represents the daytime.

istics (Shitashima et al., 2002, 2013; Shitashima, 2010). Furthermore, comparing ISFET measurements with the $\mathrm{pH}_{\mathrm{s}}$ and pH presented by Álvarez et al. (2014) suggests that the accuracy of the sensor was not as good as previously claimed (Shitashima et al., 2002). Therefore, it was necessary to correct the $\mathrm{pH}_{\mathrm{g}}$ measurements for instrumental drift, temperature, and pressure.

The response of the ISFET sensor can be described by the Nernst equation (Eq. 1), which relates sensor voltage to hydrogen ion activity:

$E=E^{*}-m_{N} \lg \left(a\left(\mathrm{H}^{+}\right) a\left(\mathrm{Cl}^{-}\right)\right)$,

which incorporates the Nernst slope (Eq. 2),

$m_{N}=R T \ln (10) / F$,

where $T$ is temperature $(\mathrm{K}), \quad R$ is the gas constant $\left(8.3145 \mathrm{~J} \mathrm{~K}^{-1} \mathrm{~mol}^{-1}\right), \quad F$ is the Faraday constant $\left(96485 \mathrm{C} \mathrm{mol}^{-1}\right), a\left(\mathrm{H}^{+}\right)$and $a\left(\mathrm{Cl}^{-}\right)$are the proton and chloride ion activities, $E$ is the measured voltage by the sensor (i.e. electromotive force), and $E^{*}$ is representative of the two half-cells in the ISFET sensor forming a circuit (i.e. interface potential) (Martz et al., 2010). It is known that temperature and pressure have an effect on $E^{*}$ (strong linear relationship) and that the Nernst slope is a function of temperature. Studies have also shown that it is possible for ISFET sensors to experience some form of hysteresis as a result of changing $T$ and pressure (Martz et al., 2010; Bresnahan et al., 2014; Johnson et al., 2016).

The first step in correcting $\mathrm{pH}_{\mathrm{g}}$ aimed to reduce the measured extent of variability to within the measured limits of $\mathrm{pH}_{\mathrm{s}}$. This in part removed the non-monotonous instrumental drift experienced by the sensor, which we think was likely due to the $E^{*}$ between the two n-type silicon parts of the semiconductor being affected. A depth-constant timevarying offset correction (i.e. one offset value determined for each dive and applied to the entire profile) was applied 
(a)

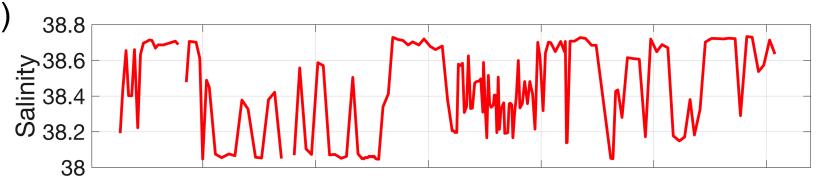

(b)

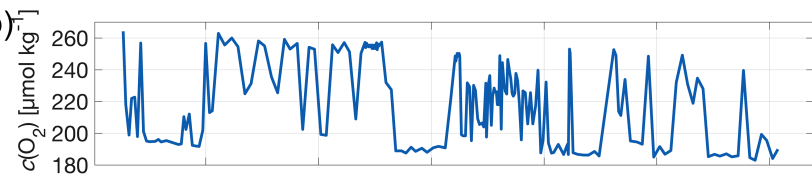

(c)

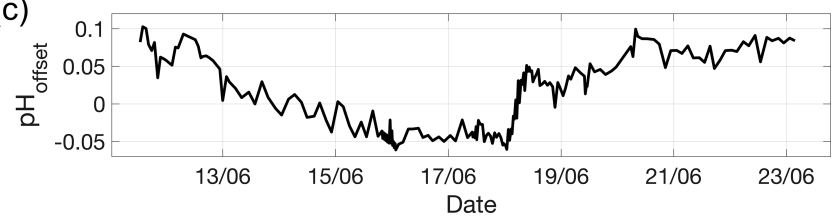

Figure 9. Salinity (a), dissolved oxygen concentrations $\left(c\left(\mathrm{O}_{2}\right)\right)(\mathbf{b})$, and the calculated $\mathrm{pH}$ offset values (c) as a function of time at the depth where the in situ temperature was $14 \pm 0.1^{\circ} \mathrm{C}$.

(Eq. 3) using the difference between the mean $\mathrm{pH}_{\mathrm{s}}$ and each $\mathrm{pH}_{\mathrm{g}}$ dive measurement where the in situ temperature was $14.0^{\circ} \mathrm{C}$, as water with this temperature was situated at a depth below the thermocline for most dives where the density gradient was weak:

$\mathrm{pH}_{\text {Offset }}=\mathrm{pH}_{\mathrm{s}}(T)_{\text {mean }}-\mathrm{pH}_{\mathrm{g}}(T)$ for $T=14 \pm 0.1^{\circ} \mathrm{C}$.

The calculated offset values as a function of time were compared with salinity and $c\left(\mathrm{O}_{2}\right)$ where the in situ temperature was constant at $14^{\circ} \mathrm{C}$ (Fig. 9). Variability in salinity and $c\left(\mathrm{O}_{2}\right)$ with time were strongly related $\left(r^{2}=0.97\right)$, whereas the relationship between $\mathrm{pH}$ offset values, salinity, and $c\left(\mathrm{O}_{2}\right)$, were not $\left(r^{2}\right.$ of around 0.2). Furthermore, the majority of the offset values were calculated below $100 \mathrm{~m}$ (Fig. 12d-f) where the density and $\mathrm{pH}$ gradients were weak. This indicated that our depth-constant time-varying offset correction decreased the apparent range of $\mathrm{pH}$ variability by an amount that was mostly associated with instrumental drift rather than physical and biogeochemical variability. Applying these offsets to the data decreased the range of $\mathrm{pH}$ measured by the ISFET sensor by approximately two-thirds (Fig. 11), with new $\mathrm{pH}_{\mathrm{g}}$ standard deviations ranging between 0.009 and 0.048 within the top $150 \mathrm{~m}$ and between 0.008 and 0.017 at greater depths.

After applying this offset correction, $\mathrm{pH}_{\mathrm{g}}$ was further corrected for in situ temperature and pressure using linear regression models. The method is outlined below.

1. Calculate $\Delta \mathrm{pH}$ (Eq. 4) as the difference between the mean $\mathrm{pH}_{\mathrm{s}}$ and $\mathrm{pH}_{\mathrm{g}}$ :

$$
\Delta \mathrm{pH}=\mathrm{pH}_{\mathrm{s}, \text { mean }}-\mathrm{pH}_{\mathrm{g}} \text {. }
$$

2. Determine the line of best fit between $\Delta \mathrm{pH}$ and in situ temperature in the top $100 \mathrm{~m}$ of the water column where the temperature gradient was the strongest using linear regression.

3. Correct $\mathrm{pH}_{\mathrm{g}}$ for in situ temperature for the entire water column using the slope $(m)$ and intercept $(c)$ coefficients of the best fit line in step 2 to obtain $\mathrm{pH}_{\mathrm{g}, \mathrm{tc}}$, where "tc" stands for "temperature-corrected" values.

4. Calculate the difference between $\mathrm{pH}_{\mathrm{g}, \mathrm{tc}}$ profiles and mean $\mathrm{pH}_{\mathrm{s}}$, producing $\Delta \mathrm{pH}_{\mathrm{tc}}$, using an equation similar to Eq. (4).

5. Determine the line of best fit between $\Delta \mathrm{pH}_{\mathrm{tc}}$ and pressure for the lower $900 \mathrm{~m}$ of the water column using linear regression.

6. Correct $\mathrm{pH}_{\mathrm{g}, \mathrm{tc}}$ for pressure for the entire water column using the coefficients $m$ and $c$ in a similar way to step 3 to obtain $\mathrm{pH}_{\mathrm{g}, \mathrm{tpc}}$, where "tpc" stands for "temperatureand pressure-corrected" values.

The derived equation used for correcting $\mathrm{pH}_{\mathrm{g}}$ is as follows:

$\mathrm{pH}_{\mathrm{g}, \mathrm{tpc}}=\mathrm{pH}_{\mathrm{g}}-0.021 t /{ }^{\circ} \mathrm{C}+4.5 \times 10^{-5} P / \mathrm{dbar}+0.261$,

where $t$ is in situ temperature and $P$ is pressure. A good fit was found between $\mathrm{pH}_{\mathrm{g}}$ and in situ temperature, and a reasonable fit was found with pressure (Fig. 10). The standard deviations of $\mathrm{pH}_{\mathrm{g}, \mathrm{tpc}}$ ranged between 0.008 and 0.039 in the top $150 \mathrm{~m}$ of the water column and between 0.007 and 0.013 at greater depths, corresponding to a further decrease in apparent variability of 13 to 23 and 14 to $31 \%$ respectively (Fig. 11).

Johnson et al. (2016) ran a series of temperature and pressure cycling experiments when testing an ISFET $\mathrm{pH}$ sensor based on the Honeywell Durafet ISFET. They found a temperature sensitivity of around $\partial \mathrm{pH} / \partial T=-0.018 \mathrm{~K}^{-1}$, which is similar to our calculated slope, and a pressure hysteresis of $0.5 \mathrm{mV}$ (pH of around 0.01 ) at maximum compression $(2000 \mathrm{dbar})$. This is equivalent to a pressure sensitivity of roughly $\partial \mathrm{pH} / \partial P=5 \times 10^{-6} \mathrm{dbar}^{-1}$, which is an order of magnitude smaller than in this study. This difference in pressure sensitivity could be related to the different housing materials used, as Johnson et al. (2016) used polyether ether ketone (PEEK), whereas acrylic resin was used for our sensor.

Salinity covaries with temperature and pressure, and some of the salinity dependence of the offset between $\mathrm{pH}_{\mathrm{s}}$ and $\mathrm{pH}_{\mathrm{g}}$ might have been misattributed to the regression coefficients associated with temperature and pressure. The sensor characteristics should therefore be studied in detail under controlled laboratory conditions. However, for the purposes of calibrating the high-resolution poor-accuracy measurements (relative to $\mathrm{pH}_{\mathrm{s}}$ ) obtained from the ISFET $\mathrm{pH}$ sensor, the present empirical correction based on temperature and pressure appears to be sufficient to achieve a match within the $\mathrm{pH}$ repeatability of the discrete samples between 0.004 and 0.017 . 

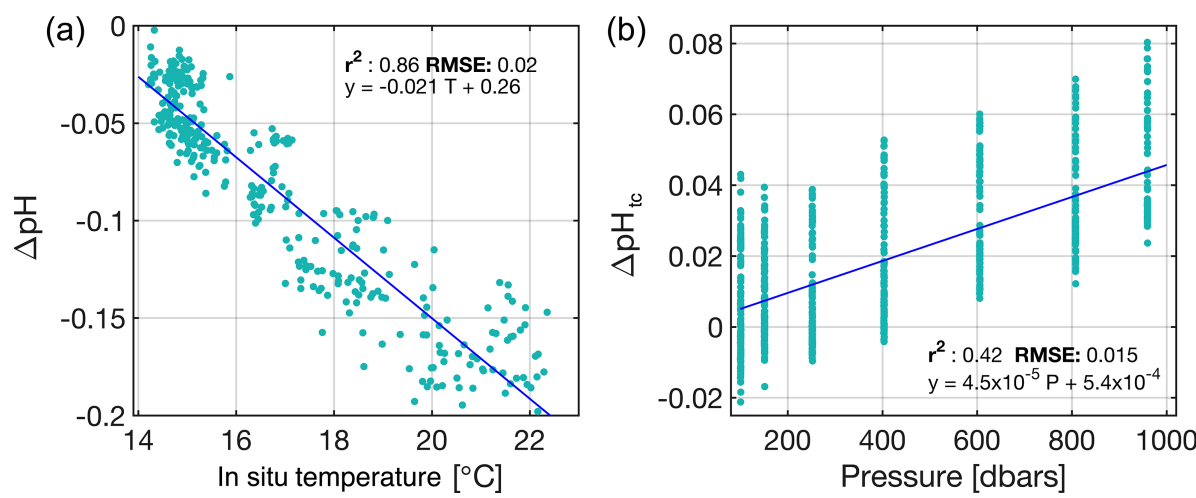

Figure 10. Linear regression fits are displayed for (a) $\Delta \mathrm{pH}$ (the difference between the mean $\mathrm{pH}_{\mathrm{s}}$ and $\mathrm{pH}_{\mathrm{g}}$ corrected for drift) vs. in situ temperature in the top $100 \mathrm{~m}$ of the water column and (b) $\Delta \mathrm{pH}$ corrected for in situ temperature $\left(\Delta \mathrm{pH}_{\mathrm{tc}}\right)$ vs. pressure between 100 and $1000 \mathrm{~m}$ using all available dives. The $r^{2}$, root mean square error (RMSE), and the equation of the line are displayed for each linear fit.

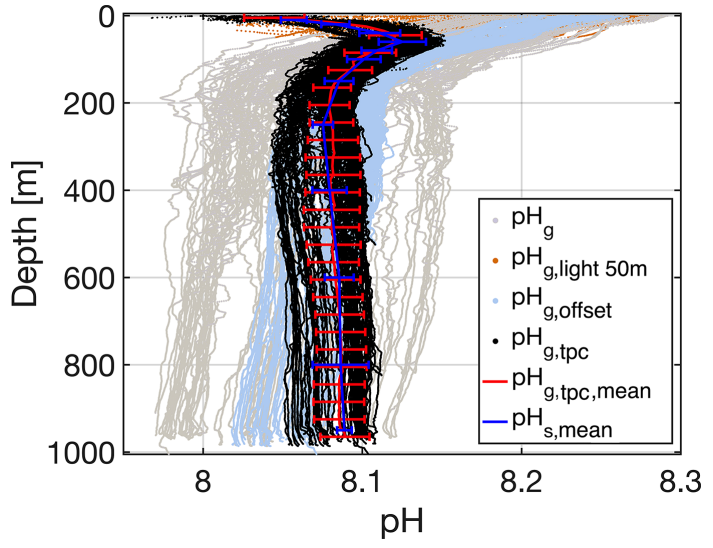

Figure 11. Profiles of glider-retrieved $\mathrm{pH}\left(\mathrm{pH}_{\mathrm{g}}\right)$ pre-correction (grey) with a depth-constant time-varying offset correction applied (light blue) and further corrected for in situ temperature and pressure (black). The $\mathrm{pH}_{\mathrm{g}}$ measurements affected by light in the top $50 \mathrm{~m}$ of the water column (orange) and not used for the drift; temperature and pressure corrections are also shown. The depth-binned mean profile of drift, temperature, and pressure-corrected (tpc) $\mathrm{pH}_{\mathrm{g}}$ (using $10 \mathrm{~m}$ bins) is shown in the foreground (red) along with the standard deviation ranges displayed every $40 \mathrm{~m}$ in this figure. The depth-binned mean profile of the $\mathrm{pH}$ measurements retrieved by ship $\left(\mathrm{pH}_{\mathrm{S}}\right)$ is plotted for comparison (dark blue) with standard deviation ranges displayed at each sampled depth.

\subsubsection{Coast to open ocean high-resolution hydrographic and biogeochemical variability}

Spatial and temporal variability can be seen in $\mathrm{pH}_{\mathrm{g}, \mathrm{tpc}}$ for three individual east-west transects using measurements obtained within different time periods (Fig. 12a-c). This $\mathrm{pH}$ variability is likely related to the air-sea exchange of carbon dioxide (weak), changes in temperature (indirectly), and biological activity (Yao et al., 2016). In the top $100 \mathrm{~m}, \mathrm{pH}$ higher than 8.12 was found at depths ranging from 20 to $95 \mathrm{~m}$, whereas lower $\mathrm{pH}$ values ranging from 8.06 to 8.09 were present closer to the surface at some locations (e.g. between 7.5 and $7.7^{\circ} \mathrm{E}$ and east of $8^{\circ} \mathrm{E}$ ). The $\mathrm{pH}$ maxima were found at depths between 40 and $70 \mathrm{~m}$ where $\theta$ was around $15^{\circ} \mathrm{C}$ (Fig. $12 \mathrm{~d}-\mathrm{f}$ ) within the pycnocline (Fig. $12 \mathrm{j}-$ 1). This band of high $\mathrm{pH}$ situated at 20 to $95 \mathrm{~m}$ of depth corresponded with a thick layer of $c\left(\mathrm{O}_{2}\right)$-rich water at similar depths (Fig. 12m-o). The pH and $c\left(\mathrm{O}_{2}\right)$ in the top $200 \mathrm{~m}$ of the water column more or less followed isopycnal surfaces at a range of points in time and space. For example, the slanted isopycnals closer to the coast (east of $7.95^{\circ} \mathrm{E}$ ) associated with geostrophic shear corresponded with horizontal gradients in $\mathrm{pH}$ and $c\left(\mathrm{O}_{2}\right)$. Below $100 \mathrm{~m}, c\left(\mathrm{O}_{2}\right)$ decreased to a minimum of $<170 \mu \mathrm{mol} \mathrm{kg}-1$; although not spatially homogeneous, this corresponded with generally colder, saltier, and lower-pH waters.

All three east-west transects can be separated into two parts roughly either side of $7.7^{\circ} \mathrm{E}$ for depths greater than $100 \mathrm{~m}$. Lower $\mathrm{pH}$ values between 8.05 and 8.1 were found in the western part, whereas a higher $\mathrm{pH}$ ranging from 8.07 to 8.12 was found in the eastern part, which was partially seen in the $\mathrm{pH}_{\mathrm{s}}$ measurements (Fig. 5). The spatial variability in these eastern and western parts differed for each of the three time periods (times labelled in Fig. 12) with both the eastern high and western low $\mathrm{pH}$ patches changing in size vertically and horizontally, corresponding to spatial changes in $\theta$ and salinity. Furthermore, salinity, $\theta$, and $c\left(\mathrm{O}_{2}\right)$ were lower in the western part compared with the values found at similar depths in the eastern section (Fig. 12d-i, m-o).

In the top $100 \mathrm{~m}$ of the water column, the variability in $\mathrm{pH}$ and $c\left(\mathrm{O}_{2}\right)$ is likely related to biological activity and air-sea gas exchange. As discussed in Sect. 3.1, a DCM within this depth range is common in the Mediterranean Sea when waters are thermally stratified and sufficient nutrients and light are available below the mixed layer (Estrada, 1996). High chlorophyll fluorescence was observed by the ship's sensor here (Fig. $4 \mathrm{~d})$. Enhanced $c\left(\mathrm{O}_{2}\right)$ values at these depths are likely the by-product of photosynthesis, and the higher $\mathrm{pH}$ 

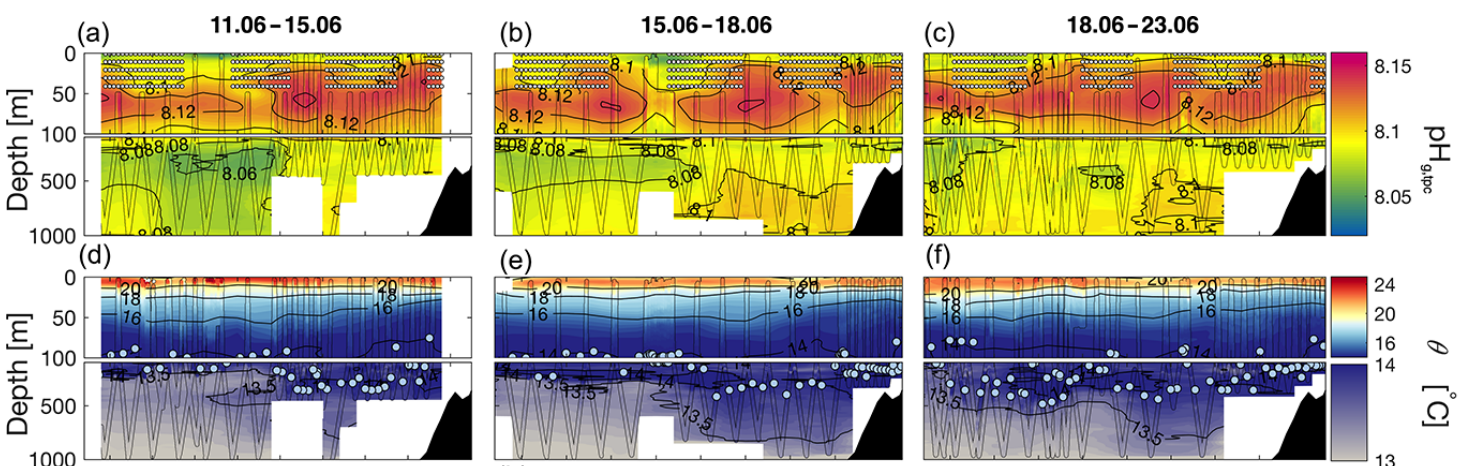

(e)
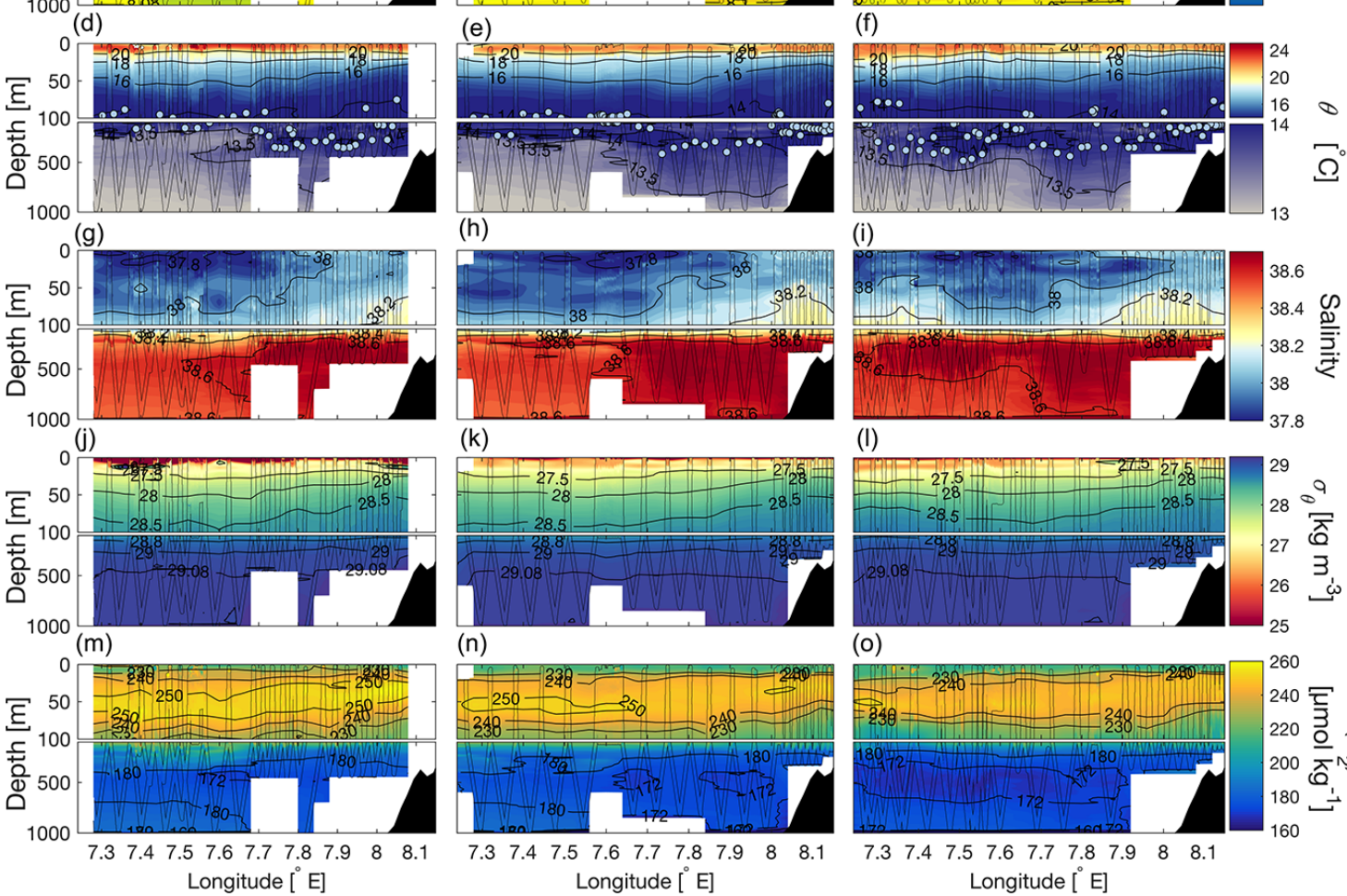

(h)
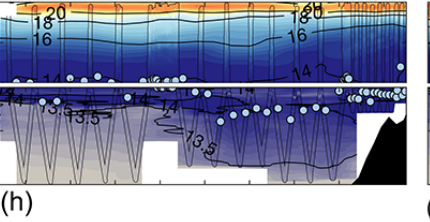

(i)

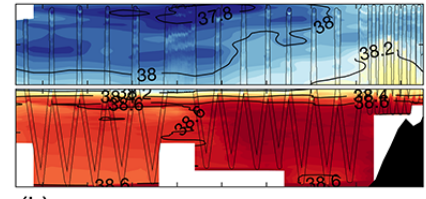

(k)
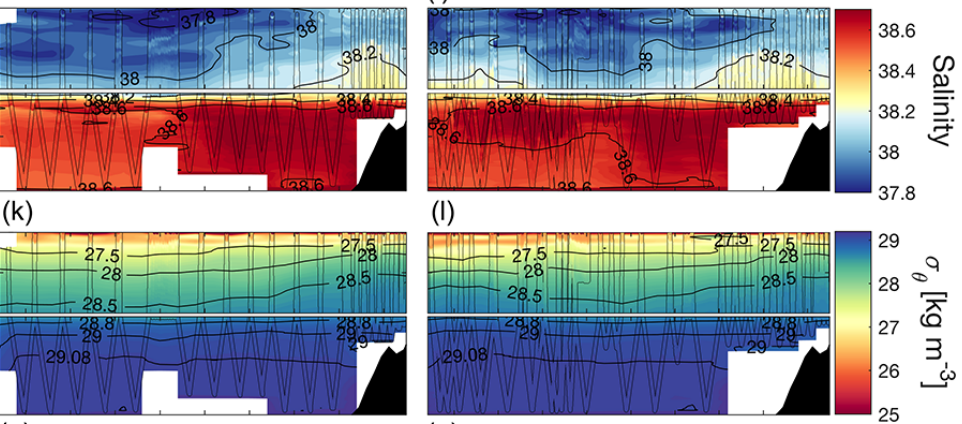

(n)

(o)
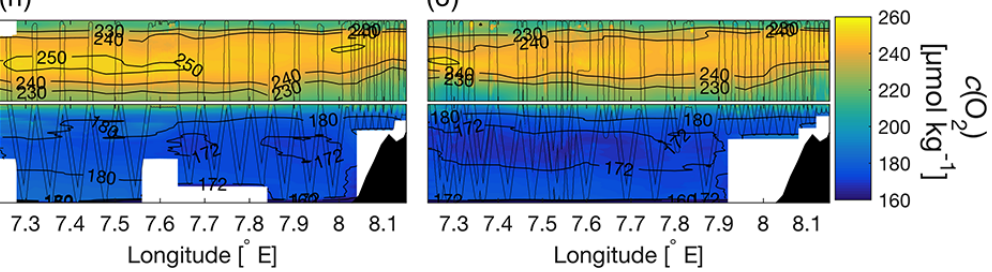

Figure 12. Objectively mapped transects of glider-retrieved $(\mathbf{a}-\mathbf{c}) \mathrm{pH}$ corrected for drift, temperature, and pressure $(\mathrm{pH}$,tpc). $(\mathbf{d}-\mathbf{f})$ Potential temperature $(\theta),(\mathbf{g}-\mathbf{i})$ salinity, $(\mathbf{j}-\mathbf{l})$ potential density anomalies $\left(\sigma_{\theta}\right)$, and $(\mathbf{m}-\mathbf{o})$ dissolved oxygen concentrations $\left(c\left(\mathrm{O}_{2}\right)\right)$ for three different time periods between 11 and 15, 15 and 18, and 18 and 23 June 2014. The spatial ranges of pH measurements affected by light and removed prior to corrections are represented by small white points (a-c). The depth-longitude points at which pH offsets were calculated at a temperature of $14{ }^{\circ} \mathrm{C}$ are indicated by pale blue points (d-f). Glider measurements were sorted into $0.04^{\circ}$ longitude $\times 2 \mathrm{~m}$ bins, and the radius of influence used for optimal interpolation was $0.1^{\circ}$ longitude $\times 10 \mathrm{~m}$. Glider measurements used for optimal interpolation are superimposed on the interpolated fields for reference.

values are likely the result of changes in the carbon equilibrium due to the consumption of $\mathrm{CO}_{2}$ (Cornwall et al., 2013; Rivaro et al., 2010; Copin-Montégut and Bégovic, 2002). A similar relationship between $\mathrm{pH}$ and primary production was described by Álvarez et al. (2014) in the western Mediterranean Sea. As discussed in Sect. 3.1, the fresher waters found in the top $100 \mathrm{~m}$ are likely MAW.

The difference in $\mathrm{pH}$ between the eastern and western parts at depths greater than $100 \mathrm{~m}$ depth highlighted the variability of water masses in this region. In particular, the higher $\mathrm{pH}$ found in the eastern part of the transect (east of $7.7^{\circ} \mathrm{E}$ ), coinciding with high $A_{\mathrm{T}}$ and $c$ (DIC) (Fig. 5), was likely related to the flow of LIW, as described in Sect. 3.1. The LIW flows from the eastern Mediterranean basin (east of the Strait of Sicily) where $\mathrm{pH}$ is higher than in the western Mediterranean basin (Álvarez et al., 2014) towards the west along the continental shelf edge (Millot, 1999). This high $\mathrm{pH}$ found in the eastern section of the glider transect may therefore be a remnant of these eastern Mediterranean waters. The low$\mathrm{pH}$ low- $c\left(\mathrm{O}_{2}\right)$ waters found deeper than $100 \mathrm{~m}$ result from increased respiration and remineralisation of organic matter (Lefèvre and Merlivat, 2012), coinciding with higher levels of $c$ (DIC) deeper than $200 \mathrm{~m}$ (Merlivat et al., 2015), which may have been more prominent in the western part of the transect (west of $7.7^{\circ} \mathrm{E}$ ) leading to decreased levels of $\mathrm{pH}$.

The pycnocline shallowed east of $7.7^{\circ} \mathrm{E}$ in the top $100 \mathrm{~m}$ of the water column during all three time periods (times labelled in Fig. 12), which corresponded with shoaling, highsalinity, low-pH, low- $c\left(\mathrm{O}_{2}\right)$ waters and high $c(\mathrm{DIC}), A_{\mathrm{T}}$, and chlorophyll fluorescence obtained by ship (Figs. 4 and 5). These features may be related to upwelling. Meteorological buoy M1 located south of the glider transect recorded an average surface wind direction of $198^{\circ}$ towards the southsouthwest, which would be favourable for coastal upwelling. 
However, the mean wind speed was only $2 \mathrm{~m} \mathrm{~s}^{-1}$, which is weak. On the other hand, salinity maxima seen at depths of 200 to $700 \mathrm{~m}$ seem to suggest an intrusion of LIW westward. An intrusion of water away from the coast towards the open ocean has been shown to increase divergence in regions close to shore with strong alongshore currents (Roughan et al., 2005). Upwelling signatures at this longitudinal range along the Sardinian coast have been simulated, particularly in the summer, by Olita et al. (2013) using a hydrodynamic 3-D mesoscale-resolving numerical model. They suggest that a mixture of both current flow and wind preconditioned and enhanced upwelling in this region, which may have also been the case during our deployment. Furthermore, chlorophyll fluorescence (Fig. 4) obtained by ship was higher closer to shore, which is indicative of a greater abundance of biomass in the top $100 \mathrm{~m}$, perhaps fuelled by upwelled nutrients (Porter et al., 2016; El Sayed et al., 1994).

\section{Conclusions}

Our trials of an experimental $\mathrm{pH}$ sensor in the Mediterranean Sea uncovered instrumental problems that were unexpected and will need to be addressed in future usage. These are summarised here.

1. The data retrieved from the dual $\mathrm{pH}-p\left(\mathrm{CO}_{2}\right)$ integrated sensor and from the $p\left(\mathrm{CO}_{2}\right)$ unit of the stand-alone dual sensor could not be used due to quality issues. It is unclear why there was a problem with the measurements obtained by the stand-alone $p\left(\mathrm{CO}_{2}\right)$ unit; however, we think the regular on/off cycling of power to the integrated dual $\mathrm{pH}-p\left(\mathrm{CO}_{2}\right)$ sensor between sampling did not allow it to function properly. In future, we would suggest the addition of backup batteries to supply electricity to the sensor between sampling.

2. The stand-alone $\mathrm{pH}$ sensor was subject to drift. This could be reduced by subtracting a depth-constant timevarying offset from each dive using the difference between $\mathrm{pH}_{\mathrm{g}}$ and $\mathrm{pH}_{\mathrm{s}}$ at a more dynamically stable depth, but such an approach is not generally recommended or valid. We think that a change in $E^{*}$ between the two n-type silicon parts of the semiconductor might be the cause of the drift. To elucidate this drift further, in future two ISFET sensors should be tested in laboratory conditions within a bridge circuit to attempt to isolate possible factors contributing to drift. Focussing on the root cause of the sensor drift rather than correcting the $\mathrm{pH}$ data for drift after the deployment would be more beneficial to the long-term study of ISFET $\mathrm{pH}-p\left(\mathrm{CO}_{2}\right)$ sensors.

3. The sensor was apparently affected by temperature and pressure, but it is unclear to what extent the empirical relationship between in situ temperature and $\Delta \mathrm{pH}$ in the thermocline (top $100 \mathrm{~m}$ ) and between pressure and $\Delta \mathrm{pH}_{\mathrm{tc}}$ in the deeper water $(100-900 \mathrm{~m})$ can be generalised.

4. The effect of light caused the sensor to measure lower levels of $\mathrm{pH}_{\mathrm{g}}$ in surface waters. This effect is expected to be ubiquitous wherever the sensor nears the surface during daytime. In future, the sensor will have to be positioned on the underside of the glider or equipped with a light shield to limit the effect of the sun when close to the surface.

Despite the overall disappointing performance, we were able to demonstrate the potential use of the corrected glider $\mathrm{pH}$ measurements to uncover the biogeochemical variability associated with biological and physical mesoscale features. The $\mathrm{pH}_{\mathrm{g}}$ corrected for drift, temperature, and pressure was compared temporally and spatially with the other physical and biogeochemical parameters obtained by the glider. This comparison indicated that the $\mathrm{pH}$ in the top $100 \mathrm{~m}$ of the water column was mostly related to biological activity where $c\left(\mathrm{O}_{2}\right)$ was high. Below $100 \mathrm{~m}$, low $\mathrm{pH}$ west of $7.7^{\circ} \mathrm{E}$ was likely linked to the remineralisation of organic matter, whilst east of this point, higher $\mathrm{pH}$ may have been transported from the eastern Mediterranean basin via LIW. Shoaling isopycnals east of $7.7^{\circ} \mathrm{E}$ closer to shore may have been indicative of upwelling, and possible upwelling signatures at the same location could be seen in salinity, $\theta, \mathrm{pH}, c\left(\mathrm{O}_{2}\right), c(\mathrm{DIC}), A_{\mathrm{T}}$, and chlorophyll fluorescence.

Data availability. All REP14-MED experiment data are available on the CMRE data server at http://geos3.cmre.nato.int/ portal/ (NATO Centre for Maritime Research and Experimentation (CMRE), 2016). The data are NATO UNCLASSIFIED and available only for the partners of the experiment. However, interested institutions can sign up for partnership at any time. Requests may be directed to the author or to geos-webmaster@nurc.nato.int.

Competing interests. The authors declare that they have no conflict of interest.

Acknowledgements. The authors would like to thank all the partners who helped make REP14-MED a success: the engineers, technicians, and scientists onboard the NRV Alliance and the NRV Planet, those on land responsible for the logistics of the experiment, and the UEA glider science team for piloting the glider. We thank Bastien Queste and Gillian Damerell for their help and support regarding the analysis of the glider data. Michael Hemming's $\mathrm{PhD}$ project is funded by the Defence Science and Technology Laboratory (DSTL, UK), in close cooperation with Direction Générale de l'Armement (DGA, France), with oversight provided by Tim Clarke and Carole Nahum. We thank the Natural Environment Research Council (NERC, UK) for providing financial support for the demonstration of the glider capability. 
Edited by: J. Chiggiato

Reviewed by: three anonymous referees

\section{References}

Álvarez, M., Sanleón-Bartolomé, H., Tanhua, T., Mintrop, L., Luchetta, A., Cantoni, C., Schroeder, K., and Civitarese, G.: The $\mathrm{CO}_{2}$ system in the Mediterranean Sea: a basin wide perspective, Ocean Sci., 10, 69-92, doi:10.5194/os-10-69-2014, 2014.

Aßmann, S., Frank, C., and Körtzinger, A.: Spectrophotometric high-precision seawater $\mathrm{pH}$ determination for use in underway measuring systems, Ocean Sci., 7, 597-607, doi:10.5194/os-7597-2011, 2011.

Bates, N. R., Best, M. H. P., Neely, K., Garley, R., Dickson, A. G., and Johnson, R. J.: Detecting anthropogenic carbon dioxide uptake and ocean acidification in the North Atlantic Ocean, Biogeosciences, 9, 2509-2522, doi:10.5194/bg-9-2509-2012, 2012.

Binetti, U.: Dissolved oxygen-based annual biological production from glider observations at the Porcupine Abyssal Plain (North Atlantic), Ph.D. thesis, University of East Anglia, 2016.

Bittig, H. C., Fiedler, B., Scholz, R., Krahmann, G., and Körtzinger, A.: Time response of oxygen optodes on profiling platforms and its dependence on flow speed and temperature, Limnol. Oceanogr. Methods, 12, 617-636, 2014.

Bresnahan, P. J., Martz, T. R., Takeshita, Y., Johnson, K. S., and LaShomb, M.: Best practices for autonomous measurement of seawater $\mathrm{pH}$ with the Honeywell Durafet, Methods Oceanogr., 9, 44-60, 2014.

Byrne, R. H. and Breland, J. A.: High precision multiwavelength $\mathrm{pH}$ determinations in seawater using cresol red, Deep Sea Res. A, 36, 803-810, 1989.

Copin-Montégut, C. and Bégovic, M.: Distributions of carbonate properties and oxygen along the water column $(0-2000 \mathrm{~m})$ in the central part of the NW Mediterranean Sea (Dyfamed site): influence of winter vertical mixing on air-sea $\mathrm{CO}_{2}$ and $\mathrm{O}_{2}$ exchanges, Deep Sea Res. II, 49, 2049-2066, 2002.

Cornwall, C. E., Hepburn, C. D., McGraw, C. M., Currie, K. I., Pilditch, C. A., Hunter, K. A., Boyd, P. W., and Hurd, C. L.: Diurnal fluctuations in seawater $\mathrm{pH}$ influence the response of a calcifying macroalga to ocean acidification, Proc. Roy. Soc. London B, 280, 20132 201, 2013.

Dickson, A.: $\mathrm{pH}$ scales and proton-transfer reactions in saline media such as sea water, Geochem. Cosmochim. Acta, 48, 2299-2308, 1984.

Dickson, A. and Millero, F. J.: A comparison of the equilibrium constants for the dissociation of carbonic acid in seawater media, Deep Sea Res. A, 34, 1733-1743, 1987.

Dickson, A. G.: Thermodynamics of the dissociation of boric acid in synthetic seawater from 273.15 to 318.15 K, Deep Sea Res. A, 37, 755-766, 1990.

Dickson, A. G., Sabine, C. L., and Christian, J. R.: Guide to best practices for ocean $\mathrm{CO}_{2}$ measurements, PICES Special Publication 3, 191 pp., 2007.

Doney, S. C., Fabry, V. J., Feely, R. A., and Kleypas, J. A.: Ocean acidification: the other $\mathrm{CO}_{2}$ problem, Marine Sci., 1, 169-192, 2009.
El Sayed, M. A., Aminot, A., and Kerouel, R.: Nutrients and trace metals in the northwestern Mediterranean under coastal upwelling conditions, Cont. Shelf Res., 14, 507-530, 1994.

Eriksen, C. C., Osse, T. J., Light, R. D., Wen, T., Lehman, T. W., Sabin, P. L., Ballard, J. W., and Chiodi, A. M.: Seaglider: A long-range autonomous underwater vehicle for oceanographic research, Oceanic Engineering, IEEE Journal of, 26, 424-436, 2001.

Estrada, M.: Primary production in the northwestern Mediterranean, Scientia Marina, 60, 55-64, 1996.

Fabry, V. J., Seibel, B. A., Feely, R. A., and Orr, J. C.: Impacts of ocean acidification on marine fauna and ecosystem processes, ICES Journal of Marine Science: Journal du Conseil, 65, 414432, 2008.

Frajka-Williams, E., Eriksen, C. C., Rhines, P. B., and Harcourt, R. R.: Determining vertical water velocities from Seaglider, J Atmos. Ocean. Tech., 28, 1641-1656, 2011.

Garau, B., Ruiz, S., Zhang, W. G., Pascual, A., Heslop, E., Kerfoot, J., and Tintoré, J.: Thermal lag correction on Slocum CTD glider data, J. Atmos. Ocean. Tech., 28, 1065-1071, 2011.

Hofmann, G. E., Smith, J. E., Johnson, K. S., Send, U., Levin, L. A., Micheli, F., Paytan, A., Price, N. N., Peterson, B., Takeshita, Y., Matson, P. G., Crook, E. D., Kroeker, K. J., Gambi, M. C., Rivest, E. B., Frieder, C. A., Yu, P. C., and Martz, T. R.: High-frequency dynamics of ocean $\mathrm{pH}$ : a multi-ecosystem comparison, PloS one, 6, e28983, doi:10.1371/journal.pone.0028983, 2011.

Johnson, K. M., King, A. E., and Sieburth, J. M.: Coulometric $\mathrm{TCO}_{2}$ analyses for marine studies; an introduction, Marine Chem., 16, 61-82, 1985.

Johnson, K. S., Jannasch, H. W., Coletti, L. J., Elrod, V. A., Martz, T. R., Takeshita, Y., Carlson, R. J., and Connery, J. G.: DeepSea DuraFET: A pressure tolerant $\mathrm{pH}$ sensor designed for global sensor networks, Anal. Chem., 88, 3249-3256, 2016.

Key, R. M., Tanhua, T., Olsen, A., Hoppema, M., Jutterström, S., Schirnick, C., van Heuven, S., Kozyr, A., Lin, X., Velo, A., Wallace, D. W. R., and Mintrop, L.: The CARINA data synthesis project: introduction and overview, Earth Syst. Sci. Data, 2, 105121, doi:10.5194/essd-2-105-2010, 2010.

Knoll, M., Benecke, J., Russo, A., and Ampolo-Rella, M.: Comparison of CTD measurements obtained by NRV Alliance and RV Planet during REP14-MED, Technical Report WTD710083/2015 WB 34 pp., 2015 b.

Le Quéré, C., Moriarty, R., Andrew, R. M., Peters, G. P., Ciais, P., Friedlingstein, P., Jones, S. D., Sitch, S., Tans, P., Arneth, A., Boden, T. A., Bopp, L., Bozec, Y., Canadell, J. G., Chini, L. P., Chevallier, F., Cosca, C. E., Harris, I., Hoppema, M., Houghton, R. A., House, J. I., Jain, A. K., Johannessen, T., Kato, E., Keeling, R. F., Kitidis, V., Klein Goldewijk, K., Koven, C., Landa, C. S., Landschützer, P., Lenton, A., Lima, I. D., Marland, G., Mathis, J. T., Metzl, N., Nojiri, Y., Olsen, A., Ono, T., Peng, S., Peters, W., Pfeil, B., Poulter, B., Raupach, M. R., Regnier, P., Rödenbeck, C., Saito, S., Salisbury, J. E., Schuster, U., Schwinger, J., Séférian, R., Segschneider, J., Steinhoff, T., Stocker, B. D., Sutton, A. J., Takahashi, T., Tilbrook, B., van der Werf, G. R., Viovy, N., Wang, Y.-P., Wanninkhof, R., Wiltshire, A., and Zeng, N.: Global carbon budget 2014, Earth Syst. Sci. Data, 7, 47-85, doi:10.5194/essd-7-47-2015, 2015.

Lefèvre, N. and Merlivat, L.: Carbon and oxygen net community production in the eastern tropical Atlantic esti- 
mated from a moored buoy, Global Biogeochem. Cy., 26, doi:10.1029/2010GB004018, 2012.

Liao, H.-K., Wu, C.-L., Chou, J.-C., Chung, W.-Y., Sun, T.-P., and Hsiung, S.-K.: Multi-structure ion sensitive field effect transistor with a metal light shield, Sensors and Actuators B: Chemical, 61, $1-5,1999$.

Martz, T. R., Carr, J. J., French, C. R., and DeGrandpre, M. D.: A submersible autonomous sensor for spectrophotometric $\mathrm{pH}$ measurements of natural waters, Anal. Chem., 75, 1844-1850, 2003.

Martz, T. R., Connery, J. G., and Johnson, K. S.: Testing the Honeywell Durafet ${ }^{\circledR}$ for seawater $\mathrm{pH}$ applications, Limnol. Oceanogr. Methods, 8, 172-184, 2010.

McNeil, C. L. and D'Asaro, E. A.: A calibration equation for oxygen optodes based on physical properties of the sensing foil, Limnol. Oceanogr. Methods, 12, 139-154, 2014.

Mehrbach, C., Culberson, C., Hawley, J., and Pytkowics, R.: Measurement of the apparent dissociation constants of carbonic acid in seawater at atmospheric pressure, Limnol. Oceanogr., 18, 40 pp., 1973.

Merlivat, L., Boutin, J., and Antoine, D.: Roles of biological and physical processes in driving seasonal air-sea $\mathrm{CO}_{2}$ flux in the southern ocean: new insights from CARIOCA $\mathrm{pCO}_{2}$, J. Marine Syst., 147, 9-20, 2015.

Millero, F. J.: Thermodynamics of the carbon dioxide system in the oceans, Geochim. Cosmochim. Acta, 59, 661-677, 1995.

Millot, C.: Circulation in the western Mediterranean Sea, J. Marine Syst., 20, 423-442, 1999.

Mintrop, L., Pérez, F. F., González-Dávila, M., Santana-Casiano, M., and Körtzinger, A.: Alkalinity determination by potentiometry: Intercalibration using three different methods, Ciencias Marinas, 26, 23-37, 2000.

NATO Centre for Maritime Research and Experimentation (CMRE): Geo Spatial Data Portal, available at: http://geos3. cmre.nato.int/portal, last access: May 2016.

Olita, A., Ribotti, A., Fazioli, L., Perilli, A., and Sorgente, R.: Surface circulation and upwelling in the Sardinia Sea: A numerical study, Cont. Shelf Res., 71, 95-108, 2013.

Onken, R., Fiekas, H.-V., Beguery, L., Borrione, I., Funk, A., Hemming, M., Heywood, K. J., Kaiser, J., Knoll, M., Poulain, P.-M., Queste, B., Russo, A., Shitashima, K., Siderius, M., and ThorpKüsel, E.: High-Resolution Observations in the Western Mediterranean Sea: The REP14-MED Experiment, Ocean Sci. Discuss., doi:10.5194/os-2016-82, in review, 2016.

Orr, J. C., Epitalon, J.-M., and Gattuso, J.-P.: Comparison of ten packages that compute ocean carbonate chemistry, Biogeosciences, 12, 1483-1510, doi:10.5194/bg-12-1483-2015, 2015.

Piterbarg, L., Taillandier, V., and Griffa, A.: Investigating frontal variability from repeated glider transects in the Ligurian Current (North West Mediterranean Sea), J. Marine Syst., 129, 381-395, 2014.

Porter, M., Inall, M., Hopkins, J., Palmer, M., Dale, A., Aleynik, D., Barth, J., Mahaffey, C., and Smeed, D.: Glider observations of enhanced deep water upwelling at a shelf break canyon: A mechanism for cross-slope carbon and nutrient exchange, J. Geophys. Res.-Oceans, 121, 7575-7588, 2016.

Queste, B. Y., Heywood, K. J., Kaiser, J., Lee, G., Matthews, A., Schmidtko, S., Walker-Brown, C., and Woodward, S. W.: Deployments in extreme conditions: Pushing the boundaries of Seaglider capabilities, in: Autonomous Underwater Vehicles (AUV), 2012 IEEE/OES, 1-7, IEEE, 2012.

Rhein, M., Rintoul, S., Aoki, S., Campos, E., Chambers, D., Feely, R., Gulev, S., Johnson, G., Josey, S., Kostianoy, A., Mauritzen, C., Roemmich, D., Talley, L. D., and Wang, F.: Chapter 3: Observations: Ocean, Climate Change, 255-315, 2013.

Rivaro, P., Messa, R., Massolo, S., and Frache, R.: Distributions of carbonate properties along the water column in the Mediterranean Sea: Spatial and temporal variations, Marine Chem., 121, 236-245, 2010.

Roemmich, D. H., Davis, R. E., Riser, S. C., Owens, W. B., Molinari, R. L., Garzoli, S. L., and Johnson, G. C.: The argo project. global ocean observations for understanding and prediction of climate variability, Tech. rep., DTIC Document, 2003.

Roughan, M., Terrill, E. J., Largier, J. L., and Otero, M. P.: Observations of divergence and upwelling around Point Loma, California, J. Geophys. Res.-Oceans, 110, C04011, doi:10.1029/2004JC002662, 2005.

Shitashima, K.: Evolution of compact electrochemical in-situ $\mathrm{pH}-\mathrm{pCO}_{2}$ sensor using ISFET-pH electrode, in: Oceans 2010 MTS/IEEE Seattle, 1-4, 2010.

Shitashima, K., Kyo, M., Koike, Y., and Henmi, H.: Development of in situ pH sensor using ISFET, in: Underwater Technology, 2002. Proceedings of the 2002 International Symposium on, 106-108, IEEE, 2002.

Shitashima, K., Maeda, Y., and Ohsumi, T.: Development of detection and monitoring techniques of $\mathrm{CO}_{2}$ leakage from seafloor in sub-seabed $\mathrm{CO}_{2}$ storage, Appl. Geochem., 30, 114-124, 2013.

Takeshita, Y., Martz, T. R., Johnson, K. S., and Dickson, A. G.: Characterization of an ion sensitive field effect transistor and chloride ion selective electrodes for $\mathrm{pH}$ measurements in seawater, Anal. Chem., 86, 11189-11195, 2014.

Touratier, F. and Goyet, C.: Impact of the Eastern Mediterranean Transient on the distribution of anthropogenic $\mathrm{CO}_{2}$ and first estimate of acidification for the Mediterranean Sea, Deep Sea Res. I, 58, 1-15, 2011.

Uppström, L. R.: The boron/chlorinity ratio of deep-sea water from the Pacific Ocean, in: Deep Sea Research and Oceanographic Abstracts, vol. 21, 161-162, Elsevier, 1974.

Van Heuven, S., Pierrot, D., Rae, J., Lewis, E., and Wallace, D.: MATLAB program developed for $\mathrm{CO}_{2}$ system calculations, ORNL/CDIAC-105b, Carbon Dioxide Inf, Anal. Cent., Oak Ridge Natl. Lab., US DOE, Oak Ridge, Tennessee, 2011.

Wlodarski, W., Bergveld, P., and Voorthuyzen, J.: Threshold voltage variations in $n$-channel MOS transistors and MOSFET-based sensors due to optical radiation, Sensors and Actuators, 9, 313321, 1986.

Yao, K. M., Marcou, O., Goyet, C., Guglielmi, V., Touratier, F., and Savy, J.-P.: Time variability of the north-western Mediterranean Sea pH over 1995-2011, Marine Environ. Res., 116, 51 60, 2016.

Yates, K. K., Dufore, C., Smiley, N., Jackson, C., and Halley, R. B.: Diurnal variation of oxygen and carbonate system parameters in Tampa Bay and Florida Bay, Marine Chem., 104, 110-124, 2007.

Zeebe, R. E. and Wolf-Gladrow, D. A.: $\mathrm{CO}_{2}$ in seawater: equilibrium, kinetics, isotopes, Gulf Professional Publishing, 2001. 